\title{
Linking of Financial Data with Non-Financial Information on CSR of Companies Listed on the Stock Exchange in Poland - Polish Case Study
}

\author{
Małgorzata Anna Węgrzyńska* \\ 1 Poznań University of Life Sciences. Department of Economics; malgorzata.wegrzynska@up.poznan.pl \\ * Correspondence: malgorzata.wegrzynska@up.poznan.pl
}

\begin{abstract}
Reporting on CSR activities has become the essence of reporting for modern business entities. In this regard, particular attention is paid to public interest companies. Therefore, the following paper aims to answer the question of whether there are differences in the linguistic structure of the studied CSR reports in three selected industry indices on the Warsaw Stock Exchange (WSE) in Poland, i.e. WIG-energy index, WIG-fuel index, WIG-mining index and their relationship with the performance of selected companies. The study was conducted on a purposely selected sample of companies between 2013 and 2018. A total of 138 CSR reports and 138 annual separate financial statements prepared in accordance with international balance sheet law were collected. The study was carried out based on a panel regression model. It was found that CSR reports contained similar average percentages of parts of speech such as nouns and adjectives. When linking the economic performance of companies, expressed with selected indices, to the information on the implementation of CSR concepts, it was revealed that the results are more likely to describe business performance when it is satisfactory.
\end{abstract}

Keywords: CSR; non-financial reporting; non-financial disclosures

\section{Introduction}

Humans have been telling stories since birth [1, 2], and it is our natural method of communicating with the environment. Communication through language is also used by business entities when interacting with stakeholders. That is why storytelling has become a powerful tool that provides an opportunity to better distinguish a given business entity from others [3,4] with simultaneous use of modern communication tools (i.e. creating stories, social media, visual elements, properly directed sets of words to targeted audiences, etc.). These tools play a key role in the strategy and development of a business entity, as well as constitute one of the quickest, most powerful and effective ways to breathe new life into a business entity [5]. The advantages of using language in communication with stakeholders have also been indicated by those who prepare reports on the company's activities and those responsible for accounting. For this reason, accounting is also referred to as the language of business $[6,7,8,9]$, and the use of language in accounting is mainly related to the description of activities performed by business entities, which is also exemplified by numerous research studies, such as by Beattie V. $(2014,2004)[10$, 11]; Llewellyn, S. (2019) [12], Couper-Kuhlen, E. (2007) [13]. The use of linguistic strengths and capabilities is also carried out when reporting on Corporate Social Responsibility (CSR), as a result of which companies report on the activities of business units by primarily relying on the power of language. It is possible to notice significant development of scientific research in the field of description in accounting and a great emphasis placed on non-financial reporting within the framework of integrated reporting (IR), i.e. describing the company's activities of environmental, governance and social nature using words [14]. This area has been studied by many researchers. Among the most recognised works are 
those of Gray (1992, 2000, 2002, 2010) [15-18], Bebbington (2001, 2007, 1996) [19-21], Cooper (1992) [22], Cooper et al. (2005) [23], Jones (1996, 2003) [24, 25] and Beattie (2004, 2014) $[10,11]$. Therefore, the aforementioned research confirms that accounting is the language of business, which constitutes an unambiguous means of communication for decisions concerning investment and economic development [26], while verbal description is another element of competitive advantage of companies besides financial performance. From this point of view, the accounting system and its end product, i.e. the financial statement, play two important roles in the market economy. Firstly, accounting allows providers to assess their capital and the possibility of achieving a return on their investment. Secondly, financial statements allow investors to monitor the use of capital they have invested [27]. In other words, reporting should involve a set of policies and operational practices that enhance the competitiveness of the business entity, as well as improve economic and social conditions in the communities in which they operate [28]. In short, it is another method of spreading the economic wealth by creating social benefits, where competitiveness and profit are driven by meeting community needs [29]. At the same time, there are significant divisions and ongoing disputes separating storytelling enthusiasts and supporters of numbers. This discussion is most evident when it comes down to qualitative factors. According to the storytellers, an obvious drawback of valuation models is that they do not take into account organisational culture, the quality of managing staff and regular employees, as well as many other soft factors that affect the perception of the business entity as a whole [30].

Attempts to evaluate environmental disclosures were recorded as early as the $1970 \mathrm{~s}$ [31-38]. Following that period, this research area was abandoned by scholars who readdressed the issue in the late 20th century. The return to assessing environmental disclosures thus falls within broad contemporary research on business reporting that includes financial and non-financial reporting. Currently, no research is conducted in this respect in Poland, especially in public interest companies listed in stock indices: WIG-energy, WIG-fuel and WIG-mining. Few studies conducted in Poland were based on the concepts of disclosure research, but they lack the tools to verify the hypotheses they set out. This may be an approach that should be developed. Therefore, this article uses modern IT tools to confirm the research hypotheses posed. The first novelty of the paper is the use of tools (computer software) to analyse the text of the reports of selected companies and determine their relationship with business performance using econometric modelling. The second one consists in determining the relationship of CSR activities with the financial performance of companies from selected indices listed on the Warsaw Stock Exchange.

The article may be considered an advancement over previous research in that it contributes to a broader understanding of the possible sources of variation in research findings linking CSR to business performance in the selected industries of energy, fuels and mining.

The aim of the article, i.e. an attempt to answer the two research questions: are there differences in the linguistic structure of the studied CSR reports in selected indices of companies listed on the Warsaw Stock Exchange? and are there relationships between financial and nonfinancial information in the reports of the listed companies under study? constitutes an answer to an important problem of corporate reporting, which concerns the assessment of the consistency of financial and non-financial reporting. It should be noted that such a research approach is related to an attempt to improve the reporting information, i.e. to meet the paramount accounting principles established in the conceptual framework for International Financial Reporting Standards (IFRS) and International Accounting Standards (IAS) [39].

For the research objective thus formulated, the following research hypotheses were defined: 
Hypothesis 1: There are significant differences in the linguistic structure of the analysed CSR reports in Poland.

Hypothesis 2: There is a correlation between business performance and a description of business activity in reporting on corporate social responsibility (CSR) of companies.

\section{Review of relevant scientific research}

Studies on the link between non-financial information and financial data have been conducted by many researchers using different research methods. Researchers note that one of the most significant limitations associated with examining non-financial disclosures and financial data of companies is the difficulty of measuring the extent of voluntary disclosure [40]. The literature on the subject includes various approaches to measuring the extent of disclosure. One of such methods is an examination using qualitative tools. Among others, it consists in analysing the text through word count and sentence count, as well as determining its difficulty using readability indices such as FOG, FGL or expert methods, surveys, etc. According to Beattie, McInnes, and Fearnley (2004) [10], various approaches applied to measure disclosures can be categorised as subjective assessments or objective studies [41]. In contrast, the results of these evaluations do not provide satisfactory results. For that reason, the approach to the study of disclosures in company reporting by scholars has changed, and an effort to develop methods that combine two types of variables that affect the evaluation of disclosures has been made. The assessment of disclosures on corporate social responsibility was based on two groups of variables: qualitative variables and quantitative variables. It should be noted that such an approach is not free from error, and during evaluation or testing, these methods provide divergent results. The most commonly used quantitative and qualitative variables are listed in Table 1.

Table 1 The list of the most frequently used quantitative and qualitative variables in selected studies from the period of 2008-2017

\begin{tabular}{|c|c|c|c|c|}
\hline Year & Author(s) & Title of the article & Quantitative variables & Qualitative variables \\
\hline 2017 & $\begin{array}{c}\text { Jamal A. Nazari, } \\
\text { Karel Hrazdil, } \\
\text { Fereshteh } \\
\text { Mahmoudian }\end{array}$ & $\begin{array}{l}\text { Assessing social and environmental } \\
\text { performance through narrative } \\
\text { complexity in CSR reports }\end{array}$ & $\begin{array}{c}\text { INST, SIZE, ROA, } \\
\text { CURRAT, CAPSP, } \\
\text { PNEW, LEV, WRDS, } \\
\text { SENT, TSIZE }\end{array}$ & $\begin{array}{l}\text { Readability indices: } \\
\text { FRE, FGL, FOG, CLI, } \\
\text { SMOG, AR, AVE }\end{array}$ \\
\hline 2017 & $\begin{array}{c}\text { Wiengarten, } \\
\text { Frank; Lo, Chris } \\
\text { K.; } \\
\text { Lam, Jessie Y. }\end{array}$ & $\begin{array}{l}\text { How does sustainability leadership } \\
\text { affect firm performance? The } \\
\text { choices associated with appointing } \\
\text { a chief officer of corporate social re- } \\
\text { sponsibility }\end{array}$ & ROA & $\begin{array}{c}\text { Gender } \\
\text { Professional experi- } \\
\text { ence }\end{array}$ \\
\hline 2016 & $\begin{array}{l}\text { Verbeeten, Frank } \\
\text { H. M.; } \\
\text { Gamerschlag, } \\
\text { Ramin; Möller, } \\
\text { Klaus }\end{array}$ & $\begin{array}{l}\text { Are CSR disclosures relevant for in- } \\
\text { vestors? Empirical evidence from } \\
\text { Germany }\end{array}$ & $\begin{array}{c}\text { Share price, return per } \\
\text { share } \mathrm{RET}\end{array}$ & Readability indices \\
\hline 2015 & $\begin{array}{l}\text { Venkatraman, Si- } \\
\text { talakshmi; Nayak, } \\
\text { Raveendranath } \\
\text { Ravi }\end{array}$ & $\begin{array}{l}\text { Corporate sustainability: An IS ap- } \\
\text { proach for integrating triple bottom } \\
\text { line elements }\end{array}$ & $\begin{array}{c}\text { Top dividends for } \\
\text { shareholders, business } \\
\text { profitability, return on } \\
\text { average capital em- } \\
\text { ployed, meeting tax } \\
\text { obligations, debts/eq- } \\
\text { uity ratio }\end{array}$ & Not applicable \\
\hline
\end{tabular}




\begin{tabular}{|c|c|c|c|c|}
\hline 2014 & Wang, Chung-Jen & $\begin{array}{l}\text { Do ethical and sustainable practices } \\
\text { matter? Effects of corporate citizen- } \\
\text { ship on business performance in } \\
\text { the hospitality industry }\end{array}$ & ROI, profit growth & Not applicable \\
\hline 2013 & $\begin{array}{l}\text { Torugsa, Nut- } \\
\text { taneeya Ann; } \\
\text { O'Donohue, } \\
\text { Wayne; Hecker, } \\
\text { Rob }\end{array}$ & $\begin{array}{l}\text { Proactive CSR: An empirical analy- } \\
\text { sis of the role } \\
\text { of its economic, social and environ- } \\
\text { mental } \\
\text { dimensions on the association be- } \\
\text { tween } \\
\text { capabilities and performance }\end{array}$ & $\begin{array}{l}\text { ROA, net profits to } \\
\text { sales, liquidity }\end{array}$ & Not applicable \\
\hline 2012 & $\begin{array}{l}\text { Quazi, Ali; Rich- } \\
\text { ardson, Alice }\end{array}$ & $\begin{array}{l}\text { Sources of variation in linking cor- } \\
\text { porate social } \\
\text { responsibility and financial perfor- } \\
\text { mance }\end{array}$ & $\begin{array}{l}\text { ROA, ROE, ROI, mar- } \\
\text { ket return, market val- } \\
\text { uation, stock returns, } \\
\text { share price, EPS, sur- } \\
\quad \text { vey measures }\end{array}$ & Not applicable \\
\hline 2011 & $\begin{array}{l}\text { Hahn, Tobias; } \\
\text { Figge, Frank }\end{array}$ & $\begin{array}{l}\text { Beyond the bounded instrumental- } \\
\text { ity in current } \\
\text { corporate sustainability research: } \\
\text { Toward an } \\
\text { inclusive notion of profitability }\end{array}$ & $\begin{array}{l}\text { Capital efficiency, } \\
\text { market } \\
\text { efficiency, total sales }\end{array}$ & Not applicable \\
\hline 2010 & $\begin{array}{l}\text { Nguyen, Dung K.; } \\
\text { Slater, Stanley F. }\end{array}$ & $\begin{array}{l}\text { Hitting the sustainability sweet } \\
\text { spot: having it all }\end{array}$ & $\begin{array}{l}\text { ROA, revenue growth } \\
\text { rate, } \\
\text { share value apprecia- } \\
\text { tion rate }\end{array}$ & Not applicable \\
\hline 2009 & $\begin{array}{l}\text { Chung-Hua Shen, } \\
\text { Yuan Chang }\end{array}$ & $\begin{array}{c}\text { Ambition versus conscience, does } \\
\text { corporate social responsibility pay } \\
\text { off? The application of matching } \\
\text { methods }\end{array}$ & $\begin{array}{c}\text { ROA, ROE, PTI, RGM, } \\
\text { EPS }\end{array}$ & Not applicable \\
\hline 2008 & $\begin{array}{l}\text { Clarkson P.M., Li } \\
\text { Y., Richardson } \\
\text { G.D., Vasvari F.P.. }\end{array}$ & $\begin{array}{c}\text { Revisiting the relationship between } \\
\text { environmental performance and } \\
\text { environmental disclosure: An em- } \\
\text { pirical analysis }\end{array}$ & $\begin{array}{l}\text { EP, FIN, TOBIN, } \\
\text { VOLAT, ROA, LEV, } \\
\text { SIZE, NEW, CAPIN }\end{array}$ & GRI, EPI \\
\hline 2004 & $\begin{array}{l}\text { Al-Tuwaijri, T.E., } \\
\text { Christensen, K.E., } \\
\text { Hughes }\end{array}$ & $\begin{array}{l}\text { The relations among environmental } \\
\text { disclosure, environmental perfor- } \\
\text { mance, and economic performance: } \\
\text { a simultaneous equations approach }\end{array}$ & $\begin{array}{c}\text { SIZE, MARGIN, } \\
\text { GROWTH, ENVDISC, }\end{array}$ & $\begin{array}{l}\text { ECONPERF, EN- } \\
\text { VPERF, ENVDISCL, } \\
\text { PREDISC, }\end{array}$ \\
\hline
\end{tabular}

Table 1 presents publications that attempt to assess the disclosure of information on CSR and its possible correlation with the company performance, or solely assess the financial results of companies focused on the implementation of CSR.

The results of studies conducted by Nazari et al. (2017) [42] confirm that there are significant and negative relations between the variables under study, namely readability indices and company performance. It was determined that business units with poorer performance were more likely to be characterised by less clear information on CSR. Additionally, it was confirmed that poor financial performance determined lower CSR disclosures in the companies under study. An important finding was that companies, which renewed assets provided clearer reports on CSR. It was also indicated that ROA, CURRAT, CAPSP and LEV were not linked with the CSR report readability. A different approach was used in the study on CSR conducted by Wiengarten et al. (2017) [43], where the effect of employing a CSR director on the company's financial performance was investigated. It was found that hiring a CSR director influenced financial performance benefits 
under certain conditions. It was also concluded that the most significant financial benefits were obtained when the position of a CSR director was held by a woman with professional experience in the scope of CSR. In contrast, a study performed by Verbeten et al. (2016) [44] answered the question of whether narrative CSR disclosures are related to the value of a company. Accordingly, 130 companies that conducted business in Germany over a four-year period were examined. The research revealed that information on CSR varies depending on the CSR category, in that social disclosure is positively related to the value of a company, but environmental disclosure is not. Subsequently, studies by Venkatraman et al. (2015) [45] investigated the relationships between three areas, i.e. environmental performance, social performance and financial performance, in 85 different business entities in Australia. It was found that there are weak but positive links between the areas under study. In the case of the hospitality industry, it was determined whether economic responsibility, ethical responsibility and legal responsibility affect financial performance. The variables ROI and profit growth were applied to identify the relationship. As a result, it was concluded that the analysed areas of responsibility have little impact on the financial performance of the hospitality industry [46]. A study conducted by Torugs et al. (2013) [47] used a different approach, in which the role of the economic, social and environmental dimensions of proactive CSR on the association between three specific capabilities shared vision, stakeholder management and strategic proactivity - and financial performance in small and medium enterprises (SMEs) was identified. In the study, data from 171 Australian small and medium-sized enterprises in the machinery and equipment manufacturing sector was used and the positive impact of implementing CSR on the financial performance of the assessed companies was determined. With regards to the assessed companies, it was found out that the implementation of CSR activities improved their financial performance and had a significant positive impact on sustainable and longterm financial success. In turn, very interesting results were presented by Quazi et al. (2012) [48], who made an attempt to identify possible sources of variability in the results of previous studies that linked assumptions of CSR to the performance of a company. In the study, a meta-analysis of 51 previous studies, included in Orlitzky et al. (2003) [49], was conducted, to ensure consistency with the results of the research performed so far. The study results were surprising. The association between CSR activities and financial performance was found to be most influenced by sample size and research methodology, and it is these two factors that most significantly affect the research findings and conclusions. Subsequent studies found that most current approaches in corporate sustainability research are incompatible with the concept of sustainability. The current approaches are rooted in a limited notion of instrumentality that establishes a systematic a priori preference for economic organisational performance over environmental and social aspects [50]. Nguyen and Slater (2010) [51] conducted an interesting study, in which they compared the financial performance of recognised sustainability leaders with that of a carefully selected group of competitors using secondary data. On average, sustainability leaders were found to perform better than their competitors. However, this is only true in two out of three cases. The clear implication of this analysis was that a commitment to sustainability does not hurt financial performance and may actually improve it. Another study by Shen and Chang (2009) [52] examined the impact of CSR on the financial performance of companies operating in Taiwan and found that companies conducting CSR activities have significantly higher ROA, ROE, and PTI. At the same time, introducing CSR does not impair RGM and EPS. The lack of consistency between the environmental performance of business entities and the level of environmental disclosures, which is present in research findings, was noted by Clarkson et al. (2008) [53]. Based on a study of 191 US-based businesses, a positive relationship was found between environmental performance and the level of discretionary environmental disclosures. Importantly, the result is consistent with the predictions of the economics disclosure theory but inconsistent with the negative association predicted by socio-political theories. Nevertheless, we show that socio-political theories explain patterns in the data ("legitimisation") that cannot be explained by economics disclosure theories. Another interesting study was performed by Al-Tuwaijri et al. 
(2004) [54], with the main objective to conduct an integrated analysis of the interrelationship between environmental disclosures, environmental performance, and economic performance. The study found that good environmental performance is significantly associated with good economic performance, as well as more extensive measurable environmental disclosures.

Based on a brief review of CSR research, one may conclude that there exists a divergence of results between studies by researchers around the world in terms of determining CSR disclosures within a single country, within a single legal regulation, political system, or even the same variables. The reason behind this divergence is that there is no specific method to examine the extent of CSR disclosures and their relationship to company financial performance. Therefore, it is worthwhile to analyse and attempt to identify research methodologies for CSR disclosures and their links to company performance, particularly for public interest entities, to improve the quality of corporate reporting.

\section{Materials and methods}

\subsection{Research sample}

Since the late 1990s, a strong increase in the number of indices has been observed (benchmarks), the primary objective of which was to describe the economic situation among companies that met certain CSR requirements. The need to create that type of index was due to a large response to the emergence of the idea of socially responsible business in the process of popularising the idea [55]. However, apart from indices that are used to group companies which are clearly socially responsible, there are other types of indices on the stock exchange that are divided according to industries in which companies implement the concept of Social Responsibility of Business. Therefore, an attempt was made to examine the public interest companies listed on the Warsaw Stock Exchange in Poland (WSE), in the period from 2013 to 2018, grouped according to three industry indices i.e.: WIG-energy index (11 companies), WIG-fuel index (7 companies), WIG-mining index (5 companies). In each year, a total of 23 companies were assessed, and the sample represented $100 \%$ of all companies grouped according to each surveyed index (Table 2).

Table 2. A list of assessed companies grouped according to individual indices, during the period from 2013 to 2018 .

\begin{tabular}{|c|c|c|c|}
\hline Index & Instrument & ISIN code & Share in portfolio (\%) \\
\hline \multirow{4}{*}{} & PGE & PLPGER000010 & 49.745 \\
\cline { 2 - 4 } & TAURONPE & PLTAURN00011 & 20.901 \\
\cline { 2 - 4 } & ENEA & PLENEA000013 & 11.348 \\
\cline { 2 - 4 } & PEP & PLPLSEP00013 & 7.193 \\
\cline { 2 - 4 } & CEZ & CZ0005112300 & 4.618 \\
\cline { 2 - 4 } & MLSYSTEM & PLMLSTM00015 & 1.882 \\
\cline { 2 - 4 } & KOGENER & PLKGNRC00015 & 1.352 \\
\cline { 2 - 4 } & ZHOTON & NL0010391108 & 1.273 \\
\cline { 2 - 4 } & INTERAOLT & PLZEPAK00012 & 1.112 \\
\cline { 2 - 4 } & BEDZIN & PLT0000128621 & 0.516 \\
\hline WIG-fuels & PKNORLEN & PLPKN0000018 & 0.060 \\
\cline { 2 - 4 } & PGNIG & PLPGNIG00014 & 54.734 \\
\cline { 2 - 4 } & LOTOS & PLLOTOS00025 & 29.692 \\
\cline { 2 - 4 } & MOL & HU0000153937 & 12.392 \\
\hline
\end{tabular}




\begin{tabular}{|c|c|c|c|}
\hline \multirow{4}{*}{} & UNIMLOT & PLUNMOT00013 & 0.423 \\
\cline { 2 - 4 } & SERINUS & JE00BF4N9R98 & 0.174 \\
\cline { 2 - 4 } & SKOTAN & PLSKTAN00010 & 0.173 \\
\hline \multirow{4}{*}{$\begin{array}{c}\text { WIG-min- } \\
\text { ing }\end{array}$} & KGHM & PLKGHM000017 & 93.665 \\
\cline { 2 - 4 } & JSW & PLJSW0000015 & 5.275 \\
\cline { 2 - 4 } & BOGDANKA & PLLWBGD00016 & 0.890 \\
\cline { 2 - 4 } & PRAIRIE & AU000000PDZ2 & 0.145 \\
\hline
\end{tabular}

Source: prepared based on: [56].

The choice of the indices is deliberate and they represent industries that have a high impact on the natural environment and the surroundings in which they operate. Energy, fuel and mining industries are of strategic importance in the fulfillment of all obligations related to, i.a., environmental protection, as those industries ensure the basic good of civilisation which is access to electricity, heat and gas. The above-mentioned industries are also a major source of water, air or soil pollution and they contribute to adverse climate change. Therefore, such companies must combine, in a balanced way, the efficiency of their operations with the ecological and ethical aspects of their functioning in the social space [57]. The assessed industries, i.e.: fuel, energy and mining, are perceived as leading ones in the field of corporate philanthropy in Poland. According to a report "Corporate Foundations in Poland" [58], business entities from the aforementioned sector, right after the financial sector, most frequently establish foundations and are represented in rankings and indices in large numbers (e.g. Ranking of Responsible Companies and WIG-ESG Index, formerly known as Respect Index). The characteristics of each WIG WSE indices are presented in Table 3.

Table 3. Description of indices assessed in the study, listed on the Warsaw Stock Exchange.

\begin{tabular}{|c|c|c|}
\hline Index name & Description & Methodology \\
\hline WIG-energy & $\begin{array}{c}\text { Sector index - includes companies that partici- } \\
\text { pate in WIG index which are also qualified to } \\
\text { the "energy" sector. }\end{array}$ & \multirow{3}{*}{$\begin{array}{l}\text { Income Index. To calculate } \\
\text { it, the prices of the in- } \\
\text { cluded shares and the in- } \\
\text { come from dividends as } \\
\text { well as subscription rights } \\
\text { are taken into account. }\end{array}$} \\
\hline WIG-fuels & $\begin{array}{c}\text { Sector index - includes companies that partici- } \\
\text { pate in WIG index which are also qualified to } \\
\text { the "fuel and gas" sector. }\end{array}$ & \\
\hline WIG-mining & $\begin{array}{c}\text { Sector index - includes companies that partici- } \\
\text { pate in WIG index which are also qualified to } \\
\text { the "mining" sector. }\end{array}$ & \\
\hline
\end{tabular}

Source: prepared based on: [56].

Another criterion to select the sample was the publishing of information on the implementation of corporate social responsibility (CSR) of the businesses, in the form of CSR reports or integrated reports, in the period from 2013 to 2018, and the preparation of consolidated financial statements in accordance with international legal regulations, i.e. International Accounting Standards (IAS) and International Financial Reporting Standards (IFRS). All companies reported their activities in the filed of Corporate Social Responsibility in accordance with the Global Reporting Initiative (GRI Standard) [59], and a necessary condition was that the report had to be prepared in Polish.

Information on CSR was collected directly from the websites of the companies listed in the stock exchange or as a result of interviews conducted with employees of the investor 
relations department and obtaining documentation from them. In turn, the financial data of the examined public interest companies were obtained from the database of Emerging Markets Information Service (EMIS). A total of 138 CSR implementation reports and 138 consolidated annual financial statements were analysed (Table 4).

Table 4 A number of assessed companies, CSR reports and annual consolidated financial statements broken down by industry and year

\begin{tabular}{|c|c|c|c|c|c|c|c|c|}
\hline \multicolumn{2}{|r|}{ Specification } & 2013 & 2014 & 2015 & 2016 & 2017 & 2018 & Total \\
\hline \multirow{5}{*}{$\begin{array}{l}\text { WIG-en- } \\
\text { ergy }\end{array}$} & $\begin{array}{c}\text { Number of assessed } \\
\text { companies }\end{array}$ & 11 & 11 & 11 & 11 & 11 & 11 & 66 \\
\hline & $\begin{array}{c}\text { Number of companies } \\
\text { listed on WSE }\end{array}$ & 11 & 11 & 11 & 11 & 11 & 11 & 66 \\
\hline & $\begin{array}{c}\text { Percentage of assessed } \\
\text { companies }\end{array}$ & $100 \%$ & $100 \%$ & $100 \%$ & $100 \%$ & $100 \%$ & $100 \%$ & $100 \%$ \\
\hline & Number of CSR reports & 11 & 11 & 11 & 11 & 11 & 11 & 66 \\
\hline & $\begin{array}{c}\text { Number of financial } \\
\text { statements }\end{array}$ & 11 & 11 & 11 & 11 & 11 & 11 & 66 \\
\hline \multirow{5}{*}{$\begin{array}{l}\text { WIG- } \\
\text { fuels }\end{array}$} & $\begin{array}{c}\text { Number of assessed } \\
\text { companies }\end{array}$ & 7 & 7 & 7 & 7 & 7 & 7 & 42 \\
\hline & $\begin{array}{c}\text { Number of companies } \\
\text { listed on WSE }\end{array}$ & 7 & 7 & 7 & 7 & 7 & 7 & 42 \\
\hline & $\begin{array}{c}\text { Percentage of assessed } \\
\text { companies }\end{array}$ & $100 \%$ & $100 \%$ & $100 \%$ & $100 \%$ & $100 \%$ & $100 \%$ & $100 \%$ \\
\hline & Number of CSR reports & 7 & 7 & 7 & 7 & 7 & 7 & 42 \\
\hline & $\begin{array}{c}\text { Number of financial } \\
\text { statements }\end{array}$ & 7 & 7 & 7 & 7 & 7 & 7 & 42 \\
\hline \multirow{4}{*}{$\begin{array}{l}\text { WIG- } \\
\text { mining }\end{array}$} & $\begin{array}{c}\text { Number of assessed } \\
\text { companies }\end{array}$ & 5 & 5 & 5 & 5 & 5 & 5 & 30 \\
\hline & $\begin{array}{c}\text { Number of companies } \\
\text { listed on WSE }\end{array}$ & 5 & 5 & 5 & 5 & 5 & 5 & 30 \\
\hline & $\begin{array}{c}\text { Percentage of assessed } \\
\text { companies }\end{array}$ & $100 \%$ & $100 \%$ & $100 \%$ & $100 \%$ & $100 \%$ & $100 \%$ & $100 \%$ \\
\hline & Number of CSR reports & 5 & 5 & 5 & 5 & 5 & 5 & 30 \\
\hline \multicolumn{8}{|c|}{ Total number of assessed companies } & 138 \\
\hline \multicolumn{8}{|c|}{ Total number of CSR reports } & 138 \\
\hline \multicolumn{8}{|c|}{ Total number of analysed separate financial statements } & 138 \\
\hline
\end{tabular}

The selected sample was to answer two research questions, that is: Are there differences in the linguistic structure in the studied CSR reports of selected indices of companies listed on the Warsaw Stock Exchange? and Are there relationships between financial and non-financial information in the reports of the listed companies under study?

Following the two above-mentioned research objectives, the following two research hypotheses were identified: 
Hypothesis 1: There are significant differences in the linguistic structure of the analysed CSR reports in Poland.

Hypothesis 2: There is a correlation between business performance and a description of business activity in reporting on corporate social responsibility (CSR) of companies.

\subsection{Research methods}

The research methods were selected in a way that the research objectives could be met and the two research hypotheses could be verified. To verify the first research hypothesis which reads: There are significant differences in the linguistic structure of the analysed CSR reports in Poland (H1), a research tool for statistical analysis of text was used Jasnopis software [60]. JASNOPIS is a computer tool, with the use of which it is possible to measure whether a certain text is easy to read and understand. More difficult parts of text are selected and corrections are suggested. With the use of the programme, it is possible to analyse a message posted on a website or a self-written text. The tool analyses the linguistic form of a certain text, it calculates and presents the degree of difficulty of the text on a scale from 1 to 7 . "1" indicates easy texts, understandable for the Polish reader. "7", on the other hand, denotes the most difficult ones, specialised texts, the understanding of which usually requires special preparation. The programme helps to analyse the language used in the text, i.e.: it calculates the average length of sentences and paragraphs, determines the number of difficult words (based on the list of most often used words and subjective probability), calculates the percentage of nouns and verbs, calculates the percentage of abstract nouns, checks the length of the so-called chains of genitive cases ("assessment of the correctness of the performance of an action ..."), calculates the percentage of participles, and checks the position of individual words in various sections of the text. The tool marks potentially difficult words, sentences that are too long, paragraphs that are more difficult than the average paragraph of the text (jasnopis.pl). Jasnopis was developed by a team of employees at the University of Social Sciences and Humanities in Poland. The programmer is adapted to the conditions of the Polish language.

Following the possibilities of the software, the areas of statistical analysis of text in the CSR reports on the assessed companies that are listed on the stock exchange are presented in Table 4. Basic statistical areas of the analysed text are presented for three main areas as follows: 1 . text in numbers, 2 . average length of the text, 3 . text in percentages. Each of those areas was divided into sub-areas (Table 5).

Table 5. Areas of statistical analysis of the text in CSR reports on the assessed companies that are listed on the stock exchange.

\begin{tabular}{|c|c|c|}
\hline \multicolumn{2}{|c|}{ Area } & Description \\
\hline \multirow[t]{2}{*}{ 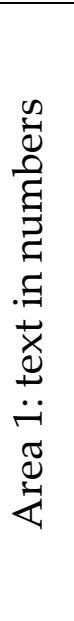 } & $\begin{array}{l}\text { Number of sen- } \\
\text { tences }\end{array}$ & $\begin{array}{l}\text { Calculated based on the number of punctuation marks and } \\
\text { marks that indicate the end of a paragraph. Punctuation } \\
\text { marks that indicate the end of a sentence are: full stops (ex- } \\
\text { cept those after abbreviations or numbers), question marks, } \\
\text { and exclamation marks. A sentence is also considered to be } \\
\text { any part of text that begins with a new paragraph or starts } \\
\text { after a punctuation mark that suggests the end of a sentence } \\
\text { and ends with an end-of-paragraph mark. }\end{array}$ \\
\hline & $\begin{array}{l}\text { Number of } \\
\text { words }\end{array}$ & $\begin{array}{c}\text { A word is any sequence of letters or numbers not separated } \\
\text { by a space or a punctuation mark (a hyphen is also consid- } \\
\text { ered to be a punctuation mark). }\end{array}$ \\
\hline
\end{tabular}




\begin{tabular}{|c|c|c|}
\hline & $\begin{array}{l}\text { Number of diffi- } \\
\text { cult words }\end{array}$ & $\begin{array}{l}\text { Difficult words are considered to be those (basic, base) that } \\
\text { consist of four syllables or more, and which are not com- } \\
\text { monly known words, i.e., one of the 5,000 words most fre- } \\
\text { quently used in Polish texts, they are also not words of a } \\
\text { high, the so-called subjective probability. }\end{array}$ \\
\hline 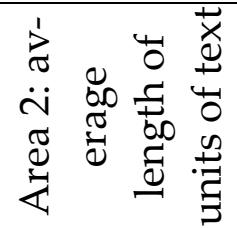 & $\begin{array}{l}\text { Average length } \\
\text { of words }\end{array}$ & $\begin{array}{l}\text { A number obtained from dividing the number of all sylla- } \\
\text { bles in a given text by the number of all words in the text. } \\
\text { The greater the average length of words, the more difficult } \\
\text { the text is to understand. }\end{array}$ \\
\hline \multirow{7}{*}{ 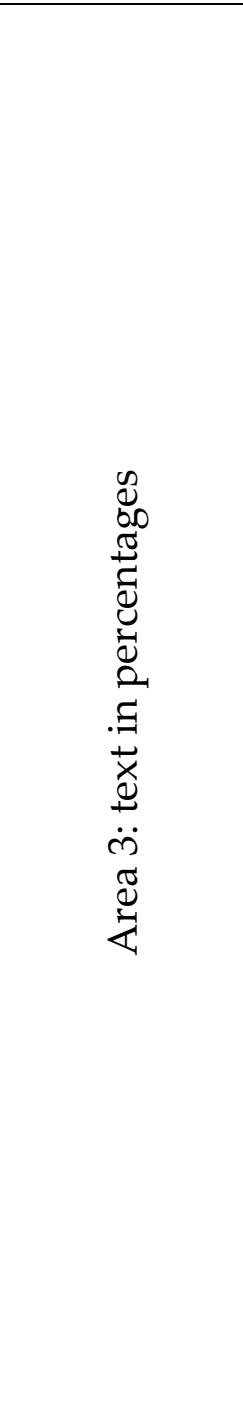 } & $\begin{array}{l}\text { Percentage of } \\
\text { difficult adjec- } \\
\text { tives }\end{array}$ & $\begin{array}{l}\text { Calculated analogously to the way in which the percentage } \\
\text { of difficult nouns is estimated. }\end{array}$ \\
\hline & $\begin{array}{l}\text { Percentage of } \\
\text { difficult verbs }\end{array}$ & $\begin{array}{l}\text { Calculated analogously to the way in which the percentage } \\
\text { of difficult nouns is estimated. }\end{array}$ \\
\hline & $\begin{array}{l}\text { Percentage of } \\
\text { difficult nouns }\end{array}$ & $\begin{array}{l}\text { Calculated as the ratio of detected occurrences of difficult } \\
\text { nouns in the text to the number of occurrences of all words } \\
\text { times } 100 \% \text {. }\end{array}$ \\
\hline & $\begin{array}{l}\text { Percentage of } \\
\text { difficult words }\end{array}$ & $\begin{array}{l}\text { Calculated as the number of words that are considered to be } \\
\text { difficult divided by the total number of words in the text } \\
\text { times } 100 \% \text {. }\end{array}$ \\
\hline & $\begin{array}{l}\text { Percentage of } \\
\text { adjectives }\end{array}$ & $\begin{array}{l}\text { Calculated as the number of different types of adjectives de- } \\
\text { tected in the text divided by the number of total words times } \\
100 \% \text {. }\end{array}$ \\
\hline & $\begin{array}{l}\text { Percentage of } \\
\text { nouns }\end{array}$ & $\begin{array}{l}\text { Calculated as the number of different types of nouns de- } \\
\text { tected in the text divided by the number of total words times } \\
100 \% \text {. Nouns are considered to be the so-called gerunds, i.e. } \\
\text { verbal nouns such as reading, spitting, noun names of fea- } \\
\text { tures such as innocence, transparency, and words such as } \\
\text { sick in a clear noun function (e.g. there were two sick lying } \\
\text { in the room). }\end{array}$ \\
\hline & $\begin{array}{l}\text { Percentage of } \\
\text { verbs }\end{array}$ & $\begin{array}{l}\text { Calculated as the number of different types of verbs de- } \\
\text { tected in the text divided by the number of total words times } \\
100 \% \text {. Adjectival and adverbial participles are not consid- } \\
\text { ered to be types of verbs. }\end{array}$ \\
\hline
\end{tabular}

Source: [Jasnopis.pl].

The second research hypothesis, which reads: There is a correlation between business performance and a description of business activity in reporting on corporate social responsibility (CSR) of companies (HY2), was verified with the use of a model of panel linear regression.

In the initial phase of the research, 75 quantitative variables that were directly related to the financial performance of the assessed companies were selected. The variables were derived from various annual consolidated financial statements that were prepared in accordance with IFRS/IAS. Additionally, the variables that were derived from financial statements were supplemented with variables derived from the calculation of indicators 
of economic and financial analysis. However, during the process of constructing and selecting variables for the study, certain variables were eliminated in accordance with the assumptions of building an econometric model, adopting the principles of elimination of variables, and taking into account the capacity of information and economic content of a quantitative variable. As a result, five quantitative variables were selected (Table 6).

Table 6. Quantitative variables used in the study.

\begin{tabular}{|c|c|c|}
\hline Variable & $\begin{array}{c}\text { Description } \\
\text { ROA (return } \\
\text { on assets) }\end{array}$ & $\begin{array}{c}\text { The ratio of a company's net income to the value of its assets. It shows the ability } \\
\text { of a certain company to generate profit and the effectiveness of managing its as- } \\
\text { sets. The higher the ROA, the better the financial situation of the company. }\end{array}$ \\
\hline Book value & $\begin{array}{c}\text { A ratio that assesses the total value of a company if it liquidated its assets and } \\
\text { paid off all its liabilities. Book value is also the net worth of a business entity. } \\
\text { It is calculated as follows: Assets - Liabilities - Priority shares - Intangible assets }\end{array}$ \\
\hline $\begin{array}{c}\text { Short-term } \\
\text { debt }\end{array}$ & $\begin{array}{c}\text { The ratio includes any financial obligations incurred by a company that must be } \\
\text { settled within 1 year. }\end{array}$ \\
\hline $\begin{array}{c}\text { Debt-to-capi- } \\
\text { tal ratio }\end{array}$ & $\begin{array}{c}\text { Assesses the value of debt that a business entity uses to finance its equity. It is } \\
\text { calculated as follows: Debt / Equity }\end{array}$ \\
\hline $\begin{array}{c}\text { Dynamics of } \\
\text { net sales rev- } \\
\text { enues }\end{array}$ & $\begin{array}{c}\text { Illustrates the increase and decrease in net sales compared to the previous fiscal } \\
\text { year. It is calculated as follows: Net sales revenue for current year / Net sales } \\
\text { revenue for previous year }\end{array}$ \\
\hline
\end{tabular}

A model of panel linear regression was formulated based on the selected variables. The weighted least squares method was used (formula 1).

Statistical analysis of the text $t_{i t}=\beta_{0}+\beta_{1}$ ROA $_{i t}+\beta_{2}$ book value vit

$+\beta_{3}$ short - term debt it $+\beta_{4}$ debt - to - capita ratio $_{i t}$ $+\beta_{5}$ dynamics of net sales revenues $i t+\varepsilon_{i t}$

Based on formula 1 above, certain models to be used in the study were constructed (Table 7).

Table 7. Models used in the study.

\begin{tabular}{|c|c|c|c|}
\hline Areas & Models & Dependent variables & Independent variables \\
\hline \multirow{3}{*}{ Area 1} & Model 1 & Number of sentences & \multirow{8}{*}{$\begin{array}{l}\text { Those variables are: } \mathrm{ROA} \text {, } \\
\text { book value, short-term debt, } \\
\text { debt-to-capital ratio, net sales } \\
\text { revenue growth. }\end{array}$} \\
\hline & Model 2 & Number of words & \\
\hline & Model 3 & Number of difficult words & \\
\hline Area 2 & Model 4 & $\begin{array}{c}\text { Average length of words [syl- } \\
\text { lables] }\end{array}$ & \\
\hline \multirow{4}{*}{ Area 3} & Model 5 & $\begin{array}{c}\text { Percentage of difficult adjec- } \\
\text { tives }\end{array}$ & \\
\hline & Model 6 & Percentage of difficult verbs & \\
\hline & Model 7 & Percentage of difficult nouns & \\
\hline & Model 8 & Percentage of difficult words & \\
\hline
\end{tabular}




\begin{tabular}{|c|c|c|c|}
\hline & Model 9 & Percentage of adjectives & \\
\hline & Model 10 & Percentage of nouns & \\
\hline & Model 11 & Percentage of verbs & \\
\hline
\end{tabular}

\section{Results}

4.1. Assessment of the linguistic structure of CSR reports on the examined companies, in the period from 2013 to 2018. Verification of the first research hypothesis.

\subsubsection{Descriptive statistics}

The first research hypothesis which reads as follows: There are significant differences in the linguistic structure of the analysed CSR reports in Poland (H1), was verified by means of statistical text analysis which was conducted in three selected areas of text analysis i.e. area 1: text in numbers, area 2: average length of text, and area 3: text in percentages.

Descriptive statistics for selected areas of text analysis for WIG-energy, for the period from 2013 to 2018, are summarised in Table 8.

Table 8. Descriptive statistics for selected areas of text analysis for WIG-energy for the period from 2013 to 2018.

\begin{tabular}{|c|c|c|c|c|c|c|}
\hline \multicolumn{2}{|c|}{ Areas of text analysis } & \multirow{2}{*}{$\begin{array}{c}\text { Average } \\
1959 \\
\end{array}$} & \multirow{2}{*}{$\begin{array}{c}\begin{array}{c}\text { Standard er- } \\
\text { ror }\end{array} \\
81 \\
\end{array}$} & \multirow{2}{*}{$\begin{array}{c}\text { Median } \\
1980 \\
\end{array}$} & \multirow{2}{*}{\begin{tabular}{|c|}
$\begin{array}{c}\text { Standard de- } \\
\text { viation }\end{array}$ \\
396 \\
\end{tabular}} & \multirow{2}{*}{$\begin{array}{c}\text { Maximum } \\
2516\end{array}$} \\
\hline \multirow{3}{*}{ 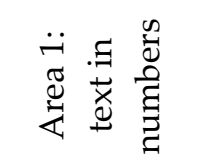 } & Number of sentences & & & & & \\
\hline & Number of words & 22908 & 2137 & 21369 & 10471 & 36996 \\
\hline & Number of difficult words & 849 & 83 & 729 & 407 & 1612 \\
\hline 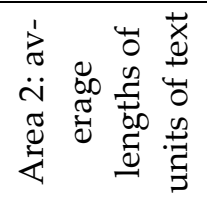 & $\begin{array}{l}\text { Average length of words } \\
\text { [syllables] }\end{array}$ & 3 & 0 & 3 & 0 & 3 \\
\hline \multirow{7}{*}{ 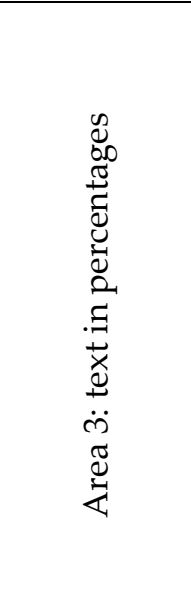 } & $\begin{array}{c}\text { Percentage of difficult ad- } \\
\text { jectives }\end{array}$ & $9.42 \%$ & $1.54 \%$ & $5.50 \%$ & $7.55 \%$ & $27.00 \%$ \\
\hline & $\begin{array}{l}\text { Percentage of difficult } \\
\text { verbs }\end{array}$ & $1 \%$ & $0 \%$ & $1 \%$ & $0 \%$ & $1.00 \%$ \\
\hline & $\begin{array}{c}\text { Percentage of difficult } \\
\text { nouns }\end{array}$ & $6 \%$ & $0.09 \%$ & $6.00 \%$ & $0.42 \%$ & $7.00 \%$ \\
\hline & $\begin{array}{l}\text { Percentage of difficult } \\
\text { words }\end{array}$ & $3.42 \%$ & $0.16 \%$ & $3.50 \%$ & $0.78 \%$ & $5.00 \%$ \\
\hline & Percentage of adjectives & $14.67 \%$ & $1.04 \%$ & $17.00 \%$ & $5.07 \%$ & $18.00 \%$ \\
\hline & Percentage of nouns & $47.67 \%$ & $1.24 \%$ & $48.00 \%$ & $6.08 \%$ & $61.00 \%$ \\
\hline & Percentage of verbs & $5.71 \%$ & $0.11 \%$ & $6.00 \%$ & $0.55 \%$ & $7.00 \%$ \\
\hline
\end{tabular}

In the case of WIG-energy index, area one of the text analysis, the average number of sentences used in CSR reports was 1,959 sentences per report, with an average word count of 22,908. In the reports on the energy industry, the number of difficult words in the total number of used words was 849 , on average. In turn, the average length of words, expressed in syllables, was three syllables. With regards to the analysis of text area in percentages, the largest percentage of words used in the text was nouns (approximately $47.65 \%$, maximum $61 \%$ ) and adjectives (approximately $14.67 \%$, maximum $18 \%$ ). The percentage of difficult adjectives in the text was significant (approximately $9.42 \%$, maximum $27 \%$ ) and the percentage of difficult verbs was insignificant - only $1 \%$ (Table 8 ). 
The description of the implementation of the CSR concept in the companies of WIGfuel index was done with 2,066 thousand sentences, on average, including 27,051 words, on average. In the reports, there were approximately 3,017 words that were considered to be difficult for the Polish reader, which accounted for approximately $11 \%$ of all words used in the reports. The words, that were used in the reports, consisted of two syllables, or a maximum of three syllables, on average. In the text, the highest proportion of parts of speech were nouns (approximately 37.56\%, maximum 49\%), followed by adjectives (approximately $15.97 \%$, maximum $23 \%$ ). The use of other parts of speech ranged from $4 \%$ to $5 \%$. In turn, the share of difficult verbs in the text was the lowest i.e.: approximately $1.33 \%$ but a maximum of $2 \%$ (Table 9 ).

Table 9. Descriptive statistics for selected areas of text analysis for WIG-energy for the period from 2013 to 2018.

\begin{tabular}{|c|c|c|c|c|c|c|c|}
\hline \multicolumn{3}{|c|}{ Areas of text analysis } & Average & Standard error & Median & $\begin{array}{c}\text { Standard devia- } \\
\text { tion }\end{array}$ & Maximum \\
\hline \multirow{3}{*}{\multicolumn{2}{|c|}{ 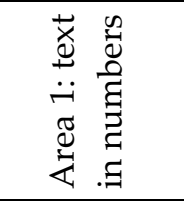 }} & Number of sentences & 2066 & 271 & 2252 & 1629 & 4192 \\
\hline & & Number of words & 27051 & 4100 & 24930 & 24602 & 69901 \\
\hline & & $\begin{array}{c}\text { Number of difficult } \\
\text { words }\end{array}$ & 3017 & 1153 & 1079 & 6920 & 31987 \\
\hline 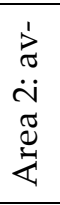 & 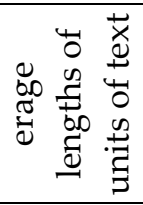 & $\begin{array}{l}\text { average length of } \\
\text { words [syllables] }\end{array}$ & 2 & 0 & 2 & 1 & 3 \\
\hline \multirow{7}{*}{\multicolumn{2}{|c|}{ 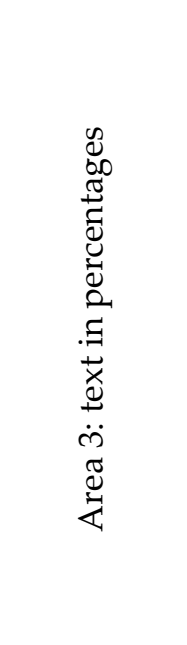 }} & $\begin{array}{l}\text { Percentage of diffi- } \\
\text { cult adjectives }\end{array}$ & $4.44 \%$ & $0.36 \%$ & $5.00 \%$ & $2.18 \%$ & $7.00 \%$ \\
\hline & & $\begin{array}{l}\text { Percentage of diffi- } \\
\text { cult verbs }\end{array}$ & $1.33 \%$ & $0.08 \%$ & $1.00 \%$ & $0.48 \%$ & $2.00 \%$ \\
\hline & & $\begin{array}{l}\text { Percentage of diffi- } \\
\text { cult nouns }\end{array}$ & $4.33 \%$ & $0.38 \%$ & $6.00 \%$ & $2.28 \%$ & $7.00 \%$ \\
\hline & & $\begin{array}{l}\text { Percentage of diffi- } \\
\text { cult words }\end{array}$ & $4.22 \%$ & $0.40 \%$ & $4.00 \%$ & $2.39 \%$ & $9.00 \%$ \\
\hline & & $\begin{array}{c}\text { Percentage of adjec- } \\
\text { tives }\end{array}$ & $15.97 \%$ & $1.24 \%$ & $18.00 \%$ & $7.43 \%$ & $23.00 \%$ \\
\hline & & Percentage of nouns & $37.56 \%$ & $2.88 \%$ & $46.00 \%$ & $17.25 \%$ & $49.00 \%$ \\
\hline & & Percentage of verbs & $5.42 \%$ & $0.50 \%$ & $7.00 \%$ & $2.99 \%$ & $8.00 \%$ \\
\hline
\end{tabular}

Descriptive statistics for selected areas of text analysis for WIG-mining, for the period from 2013 to 2018, are summarised in Table 10. With regards to the analysis of text in WIGmining, it can be noted that the largest percentage of parts of speech are nouns (approximately $46.56 \%$, maximum $51 \%$ ) and adjectives (approximately $15.28 \%$, maximum $22 \%$ ).

Table 10. Descriptive statistics for selected areas of text analysis for WIG-mining for the period from 2013 to 2018.

\begin{tabular}{|c|c|c|c|c|c|c|}
\hline \multicolumn{2}{|c|}{ Areas of text analysis } & Average & $\begin{array}{l}\text { Standard er- } \\
\text { ror }\end{array}$ & Median & $\begin{array}{l}\text { Standard de- } \\
\text { viation }\end{array}$ & Maximum \\
\hline \multirow{3}{*}{ 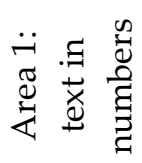 } & Number of sentences & 2493 & 111 & 2638 & 469 & 3291 \\
\hline & Number of words & 39858 & 1086 & 42802 & 4608 & 43567 \\
\hline & Number of difficult words & 12547 & 3731 & 1916 & 15827 & 34298 \\
\hline
\end{tabular}




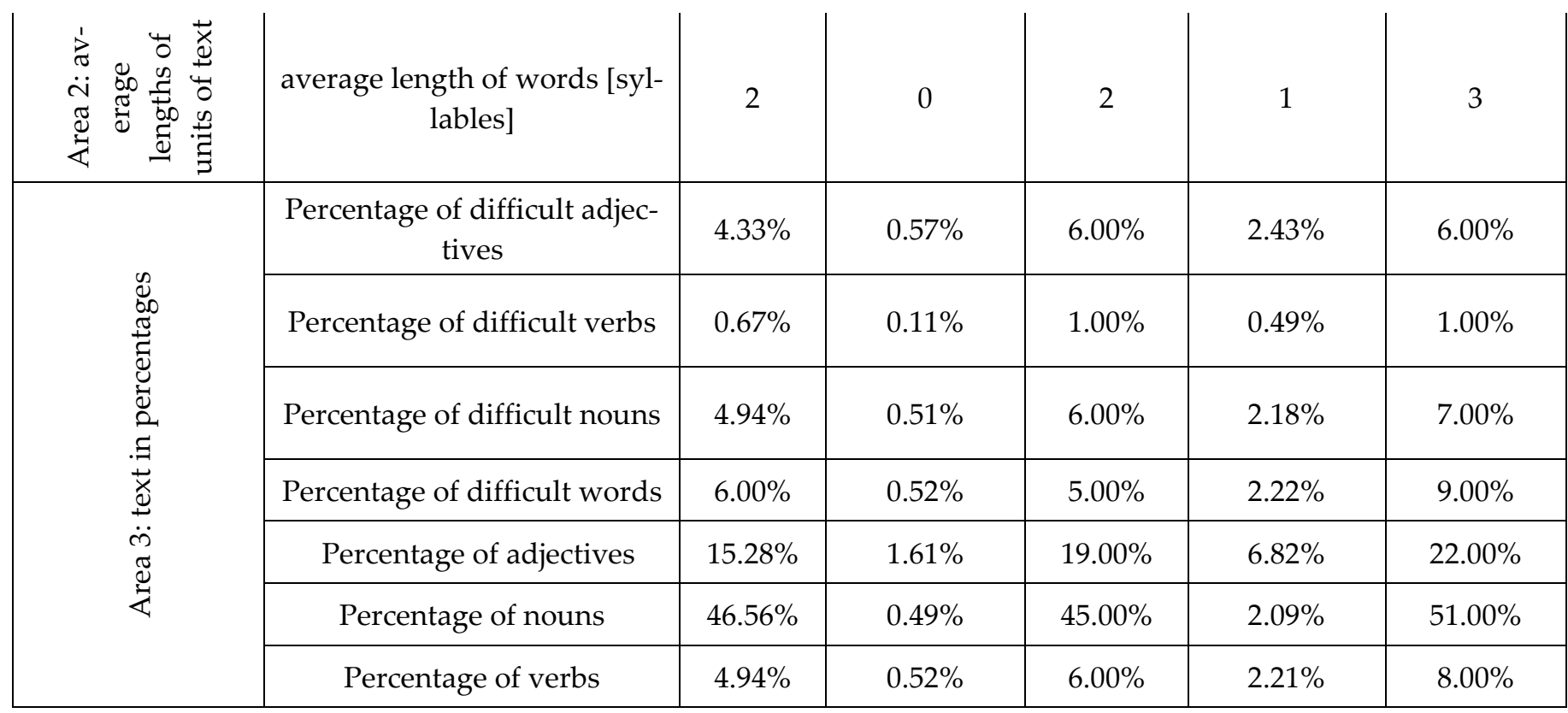

The irrelevant parts of speech included difficult verbs (0.67\%), difficult adjectives, as well as difficult nouns and verbs with percentages ranging between 4 and $5 \%$. For area one, the average number of sentences was 2,493 while the average number of words used was 39,858 , including 12,547 difficult words ( $32 \%$ of all words). As in the previous indexes, the average word length per syllable was two syllables; the maximum was three syllables.

\subsubsection{Percentage of parts of speech in the CSR reports of the researched companies}

Figure 1 shows a summary of selected parts of speech (in percentages) in the WIGenergy index. The use and application of all available language forms in the examined CSR reports of selected WIG-energy companies from the 2013-2017 period are similar, i.e. the line depicting the percentage of difficult adjectives, percentage of difficult verbs, percentage of nouns, percentage of difficult words and percentage of verbs, percentage of adjectives and percentage of nouns, overlap. As such, one may conclude that in relation to the entire sample, all companies used the given parts of speech and described nonfinancial CSR information to a similar extent. All examined WIG-energy companies reported CSR information using Polish at a similar complexity level. 


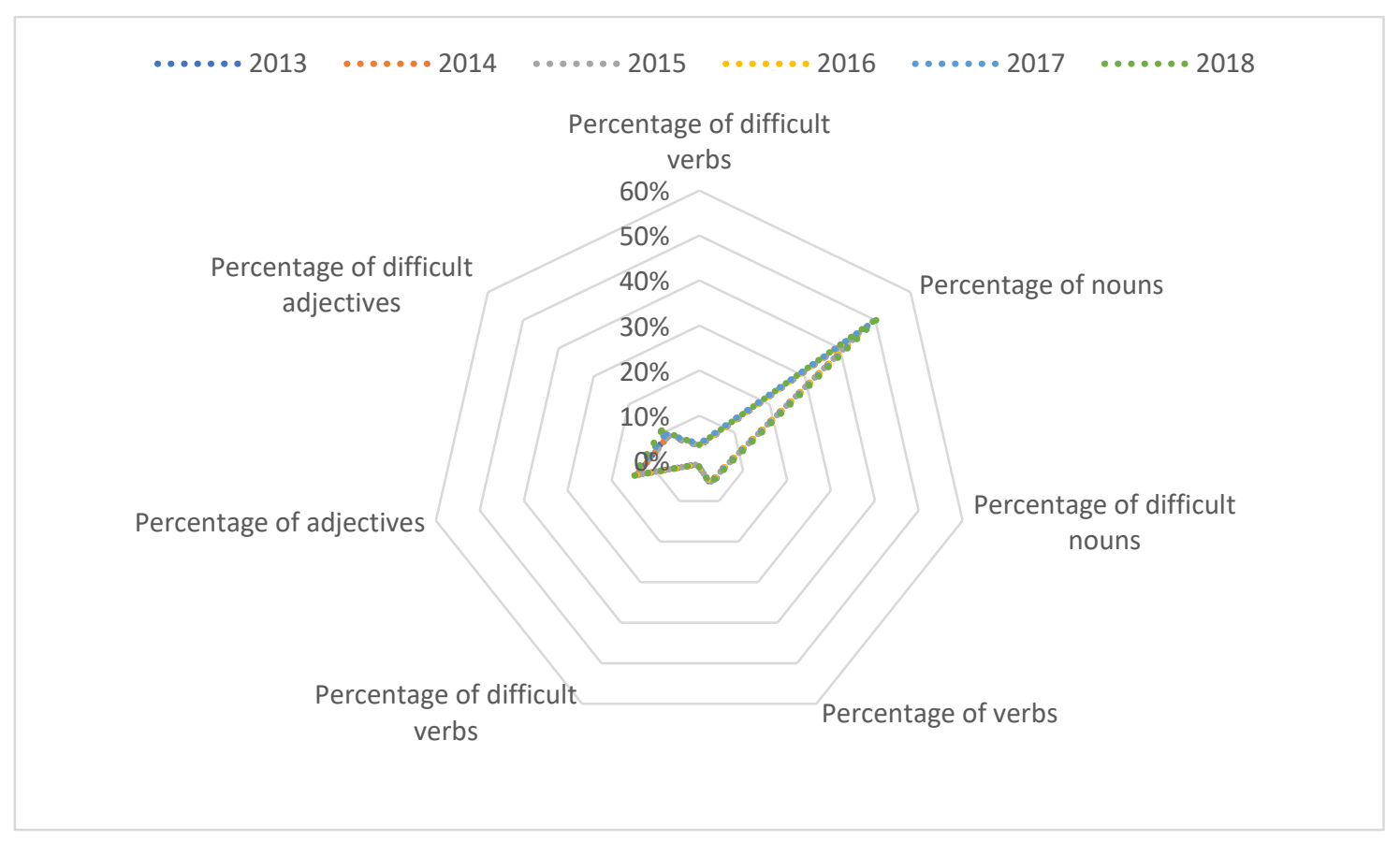

Figure 1. Percentage of parts of speech for WIG-energy from 2013 to 2018 [part of speech \%].

Nouns had the highest share in the full CSR report texts, with the average in the period studied amounting to $46 \%$ in 2013 and as high as 51\% in 2018. Adjectives were another significant part of speech. The percentage of adjectives in the CSR reports was 14\% of all parts of speech in the first year and $15 \%$ in the last year studied. Difficult verbs were the least important part of speech, accounting for $1 \%$ of all parts of speech, and this proportion was characteristic of the period as a whole.

Figure 2 shows the results of the research on the percentage of parts of speech used in the CSR reports of oil and gas industry companies in the 2013-2018 period. The analysis of the part-of-speech percentage share confirms that nouns have the largest share of all parts of speech and account for $38 \%$ on average. The second major group was adjectives, accounting for $16 \%$ of all parts of speech.

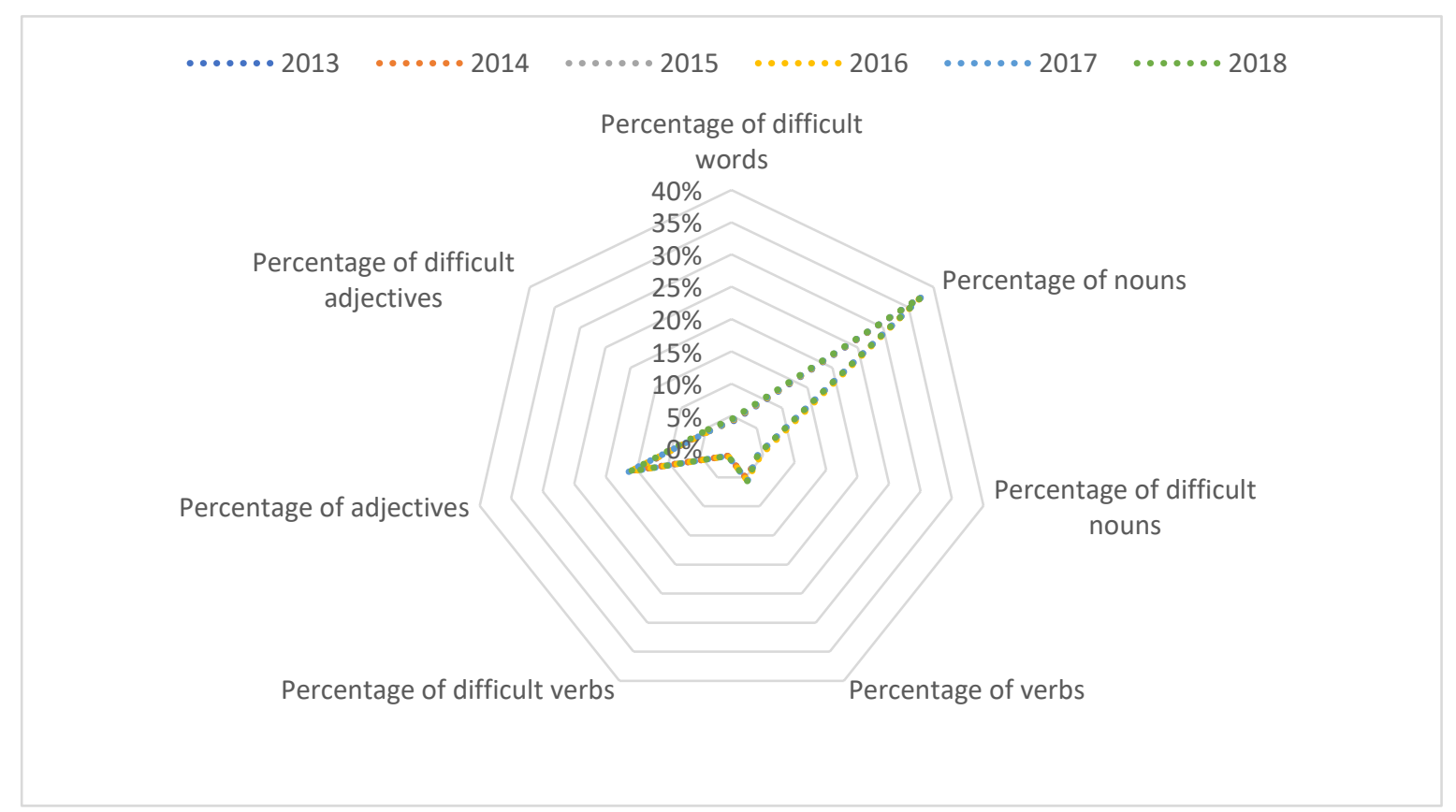

Figure 2. Percentage of parts of speech in CSR reports for WIG-fuel in the 2013-2018 period [part of speech \%]. 
In contrast, difficult verbs were the least important part of speech, accounting for an average of $1 \%$ of all parts of speech. Additionally, difficult words and difficult nouns accounted for an average of $4 \%$ of parts of speech. The percentage of verbs amounted to $5 \%$. The percentages of parts of speech in the two indices were distributed at similar levels.

Figure 3 shows a graphical representation of the CSR report analysis results for the WIG-mining index. Nouns accounted for the highest share of parts of speech. The percentage of nouns recorded in the CSR reports of companies listed in the WIG-mining index averaged $46 \%$.

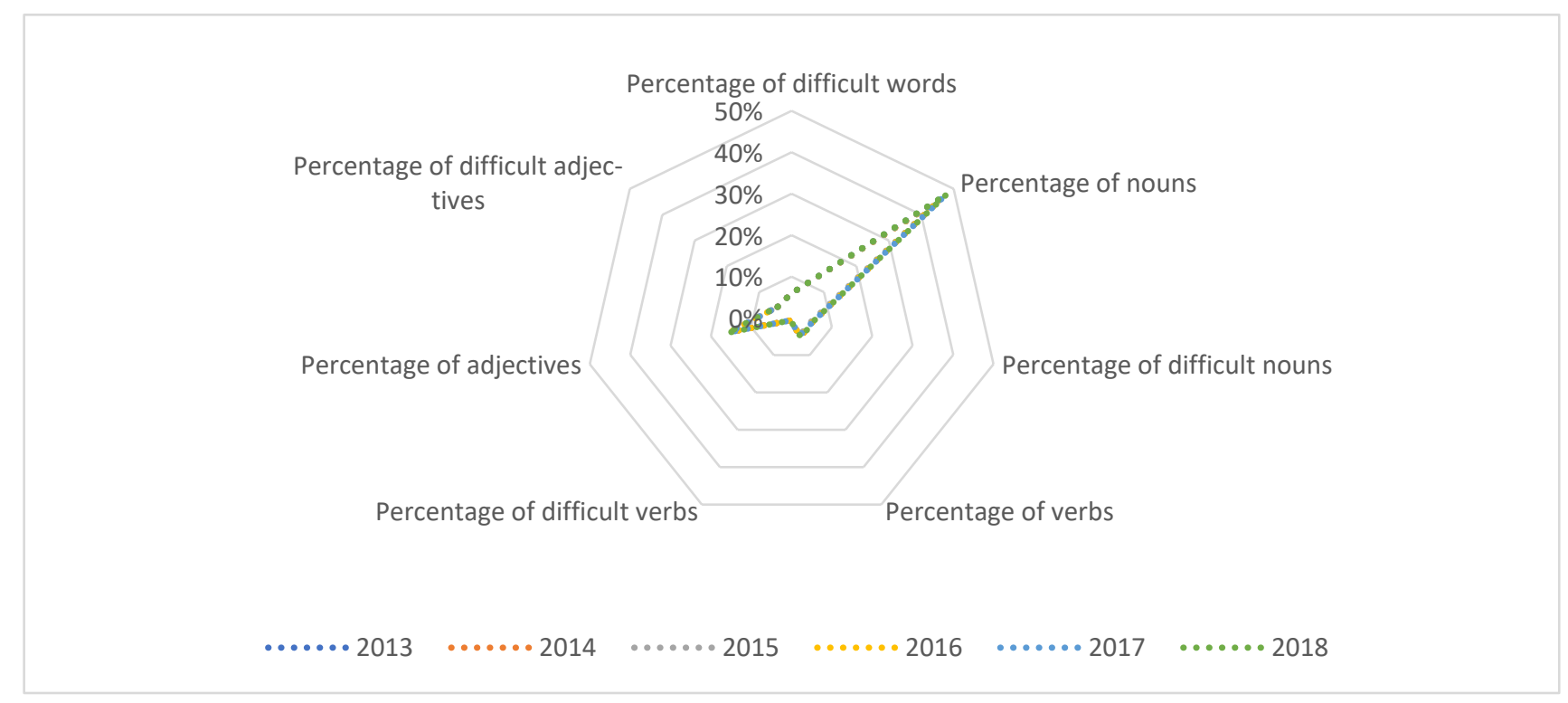

Figure 3. Percentage of parts of speech in CSR reports for WIG-mining in the 2013-2018 period [part of speech \%].

Adjectives accounted for the next largest share. They accounted for an average of $15 \%$ of all parts of speech. Among all parts of speech, difficult verbs amounted to an average of $1 \%$ of all parts of speech, and as such, had the lowest share. Next are difficult nouns, verbs, with an average of $5 \%$ of all parts of speech. Overall, difficult words accounted for $6 \%$ of all parts of speech.

4.2. Linking the performance of companies in selected stock indices to the presentation of nonfinancial CSR information in the 2013-2018 period. Verification of the second research hypothesis.

The second research hypothesis, which reads: there exists a relationship between business performance and business description in corporate social responsibility (CSR) information reporting ( $\mathrm{H} 2)$, was verified using an econometric model. Table 11 shows descriptive statistics for selected quantitative variables.

Table 11. Descriptive statistics for quantitative variables.

\begin{tabular}{|c|c|c|c|c|c|c|}
\hline Variables & Average & Standard error & Median & $\begin{array}{c}\text { Standard devia- } \\
\text { tion }\end{array}$ & Minimum & Maximum \\
\hline ROA & 0.01 & 0.02 & 0.04 & 0.09 & $(0.38)$ & 0.07 \\
\hline Book value & 15.76 & 3.52 & 9.01 & 17.26 & 1.15 & 46.76 \\
\hline Short-term debt & 0.92 & 0.26 & 0.39 & 1.26 & 0.02 & 4.57 \\
\hline $\begin{array}{c}\text { Debt-to-capital ra- } \\
\text { tio }\end{array}$ & 0.29 & 0.04 & 0.24 & 0.20 & 0.02 & 0.70 \\
\hline
\end{tabular}




\begin{tabular}{|c|c|c|c|c|c|}
$\begin{array}{c}\text { Dynamics of net } \\
\text { sales revenues }\end{array}$ & $(0.03)$ & 0.02 & $(0.03)$ & 0.08 & $(0.23)$ \\
\hline
\end{tabular}

(...) negative values.

The mean for the ROA variable was 0.01 , with this variable reaching a maximum of 0.07 with a standard deviation of 0.09 . In the case of the book value, the variable's mean value was 15.76 , with a maximum value of 46.76 . The standard deviation for this variable was 17.26. In the case of short-term debt, the average value was 0.92 and the maximum value was 4.57 . The debt-to-capital ratio averaged 0.29 . The mean value of the last variable was (0.03).

Table 12 shows Pearson correlations for selected variables. It was examined whether the variables are statistically significantly related to each other. Pearson's correlation indicates that the explanatory variables are not related to each other. In contrast, Tables 13, 14, 15 summarise the results of the panel linear regression.

For the WIG-energy index, the first area of statistical analysis of the text determined that with the text in terms of numbers - or more precisely, the number of sentences - this variable was associated with four explanatory variables, i.e. ROA, book value, short-term debt and net sales revenue dynamics. This means that the number of sentences in the CSR reports studied was influenced by the ratio of the company's net profit to the value of its assets. The number of sentences showed the relationship between the company's ability to generate profits and the efficiency of asset management. This implied a positive relationship at the high confidence level of $1 \%$, among others. The second variable affecting the number of sentences is book value. The companies showed a positive relationship between total business entity value and the number of sentences. This means that variables whose content describes the size of a company's assets, its value, or its ability to generate profits, are positively correlated with the number of sentences. This may mean that companies enjoying a stable asset situation are more willing to describe this fact using a higher number of sentences. Conversely, in the case of variables labelled as current liabilities, one may conclude that the association with the number of sentences in the CSR reports studied is negative. This may mean that WIG-energy companies did not describe this disclosure extensively or the number of sentences used has been limited. Another variable negatively related to the number of sentences is the dynamics of net sales revenue. This variable illustrates the increase and decrease in net sales compared to the previous fiscal year.

In the case of the second model from the first area explaining the changing word count, it was determined that three variables affected the number of sentences. These variables were ROA, book value, and net sales revenue dynamics. Similarly, these variables also affected the number of sentences in the first model. 
Table 12. Pearson correlation

\begin{tabular}{|c|c|c|c|c|c|c|c|c|c|c|c|c|c|c|c|c|c|c|}
\hline & 1 & 2 & 3 & 4 & 5 & 6 & 7 & 8 & 9 & 10 & 11 & 12 & 13 & 14 & 15 & 16 & 17 & 18 \\
\hline 1 & 1 & & & & & & & & & & & & & & & & & \\
\hline 2 & 0.74 & 1 & & & & & & & & & & & & & & & & \\
\hline 3 & 0.80 & 0.97 & 1 & & & & & & & & & & & & & & & \\
\hline 4 & -0.18 & -0.16 & -0.16 & 1 & & & & & & & & & & & & & & \\
\hline 5 & 0.67 & 0.96 & 0.90 & -0.17 & 1 & & & & & & & & & & & & & \\
\hline 6 & 0.59 & 0.92 & 0.81 & -0.05 & 0.93 & 1 & & & & & & & & & & & & \\
\hline 7 & 0.31 & -0.05 & 0.16 & -0.03 & -0.13 & -0.36 & 1 & & & & & & & & & & & \\
\hline 8 & -0.29 & -0.73 & -0.58 & 0.15 & -0.72 & -0.82 & 0.60 & 1 & & & & & & & & & & \\
\hline 9 & -0.01 & -0.33 & -0.19 & 0.14 & -0.33 & -0.51 & 0.54 & 0.63 & 1 & & & & & & & & & \\
\hline 10 & 0.13 & 0.32 & 0.30 & 0.02 & 0.35 & 0.23 & -0.21 & -0.42 & 0.01 & 1 & & & & & & & & \\
\hline 11 & 0.00 & 0.00 & 0.00 & 0.00 & 0.00 & 0.00 & 0.00 & 0.01 & 0.01 & 0.01 & 1 & & & & & & & \\
\hline 12 & 0.20 & 0.55 & 0.43 & 0.09 & 0.51 & 0.65 & -0.56 & -0.77 & -0.41 & 0.59 & 0.01 & 1 & & & & & & \\
\hline 13 & -0.23 & -0.65 & -0.52 & 0.10 & -0.59 & -0.73 & 0.57 & 0.89 & 0.55 & -0.49 & 0.01 & -0.95 & 1 & & & & & \\
\hline 14 & 0.42 & 0.26 & 0.26 & -0.13 & 0.32 & 0.27 & 0.06 & -0.09 & -0.04 & -0.06 & 0.01 & -0.06 & 0.02 & 1 & & & & \\
\hline 15 & 0.69 & 0.59 & 0.76 & -0.20 & 0.45 & 0.25 & 0.68 & -0.07 & 0.19 & 0.13 & 0.01 & -0.07 & -0.01 & 0.18 & 1 & & & \\
\hline 16 & 0.26 & 0.06 & 0.22 & 0.01 & 0.01 & -0.12 & 0.47 & 0.30 & 0.32 & 0.01 & 0.01 & -0.34 & 0.33 & 0.00 & 0.51 & 1 & & \\
\hline 17 & -0.49 & -0.75 & -0.63 & 0.29 & -0.79 & -0.85 & 0.40 & 0.76 & 0.53 & -0.23 & 0.01 & -0.62 & 0.72 & -0.47 & -0.10 & 0.29 & 1 & \\
\hline 18 & 0.17 & 0.09 & 0.13 & 0.22 & 0.05 & 0.13 & -0.03 & 0.03 & 0.18 & -0.01 & 0.01 & 0.16 & -0.08 & -0.32 & 0.01 & 0.29 & 0.13 & 1 \\
\hline
\end{tabular}

1 - Number of sentences, 2 - Number of words, 3 - Number of difficult words, 4 - Average word length [syllables], 5 - Average sentence length [words], 6 - Average paragraph length [words], 7 - Percentage of difficul words, 8 - Percentage of nouns, 9 - Percentage of difficult nouns, 10 - Percentage of verbs, 11 - Percentage of difficult verbs, 12 - Percentage of adjectives, 13 - Percentage of difficult adjectives, 14 - ROA, 15 - Book value, 16 Short-term debt, 17 - Debt to capital ratio, 18 - Net sales revenues growt

Table 13. Linking the performance of companies in the WIG-energy index to the presentation of non-financial CSR information in the $2013-2018$ period.

\begin{tabular}{|c|c|c|c|c|c|c|c|c|c|c|c|}
\hline Variable & Model 1 & Model 2 & Model 3 & Model 4 & Model 5 & Model 6 & Model 7 & Model 8 & Model 9 & Model 10 & Model 11 \\
\hline
\end{tabular}




\begin{tabular}{|c|c|c|c|c|c|c|c|c|c|c|c|}
\hline \multirow[b]{2}{*}{ Const } & \multicolumn{3}{|c|}{ Area 1} & \multirow{2}{*}{$\frac{\text { Area } 2}{(0.245)^{* *}}$} & \multicolumn{7}{|c|}{ Area 3} \\
\hline & $0.314 * * *$ & $7.254 * *$ & $6.177 * * *$ & & 7.752 & 0.670 & $8.139 * * *$ & $10.787 * * *$ & $4.840 * * *$ & $8.327 * * *$ & 10.728 *** \\
\hline ROA & $0.005 * * *$ & $0.215^{*}$ & $(0.060)^{* * *}$ & $(0.001)$ & 2.088 & $(0.020)$ & $(0.129)^{* * *}$ & $0.180^{* * *}$ & $(0.070)^{* * *}$ & $(0.123)^{* * *}$ & $0.149 * * *$ \\
\hline Book value & $0.008^{* *}$ & $0.729 * * *$ & $(0.028)$ & $(0.231)^{* * *}$ & (5.795) & $(2.177)^{* * * *}$ & $(0.113)^{* * *}$ & $0.110^{* *}$ & $0.098 * *$ & 0.053 & 0.029 \\
\hline Short-term debt & $(0.050)^{* * * *}$ & $(0.821)$ & $0.241 * * *$ & $(0.001)$ & $(0.020)^{* * *}$ & $(0.001)$ & $1.039 * * *$ & $1.067 * * *$ & $0.871 * * *$ & $0.637 * * *$ & $0.624 * * *$ \\
\hline Debt-to-capital ratio & $(0.006)$ & $(0.168)$ & 0.125 & $(0.001)$ & $(0.034)^{* * *}$ & 0.001 & 0.030 & 0.067 & $(0.119)$ & 0.052 & 0.082 \\
\hline $\begin{array}{c}\text { Dynamics of net sales } \\
\text { revenues }\end{array}$ & $(0.091)^{* * *}$ & $4.406^{* *}$ & $(0.189)$ & $(2.0631)^{* * *}$ & $(2.0023)^{* * *}$ & $(1.657)^{* * *}$ & $(1.238)^{* * *}$ & $(1.327)^{* * *}$ & $(1.550)^{* * *}$ & $(1.406)^{* * *}$ & $(1.025)^{* * *}$ \\
\hline Adjusted R-squared & 0.74 & 0.75 & 0.72 & 0.84 & 0.81 & 0.79 & 0.87 & 0.88 & 0.79 & 0.78 & 0.81 \\
\hline
\end{tabular}

*** significant at $1 \%$ level, $* *$ significant at $5 \%$ level, * significant at $10 \%$ level, (...) negative values

Table 14. Linking the performance of companies in the WIG-fuel index to the presentation of non-financial CSR information in the 2013-2018 period.

\begin{tabular}{|c|c|c|c|c|c|c|c|c|c|c|c|}
\hline Variable & Model 1 & Model 2 & Model 3 & Model 4 & Model 5 & Model 6 & Model 7 & Model 8 & Model 9 & Model 10 & Model 11 \\
\hline
\end{tabular}




\begin{tabular}{|c|c|c|c|c|c|c|c|c|c|c|c|}
\hline \multirow[b]{2}{*}{ Const } & \multicolumn{3}{|c|}{ Area 1} & \multirow{2}{*}{$\frac{\text { Area } 2}{0.3143^{* * *}}$} & \multicolumn{7}{|c|}{ Area 3} \\
\hline & $8.276^{* * * *}$ & $11.339 * * *$ & $4.234 * * *$ & & $6.176^{* * *}$ & $4.811 * * *$ & 0.1252 & $8.1395 * * *$ & $(3.3524)^{*}$ & $10.787 * * *$ & $(7.259)^{* * * *}$ \\
\hline ROA & $(0.108)^{* * * *}$ & $(0.139)^{* * *}$ & $(0.082)^{* * *}$ & $(0.0058)^{* * *}$ & $(0.060)^{* * *}$ & $(0.073)^{* * *}$ & $(0.1890)$ & $(0.1298)^{* * *}$ & $(0.3855)^{*}$ & $(0.1800)^{* * *}$ & $(0.4333)$ \\
\hline Book value & $0.007^{* *}$ & $0.699 * * *$ & $(0.025)$ & $0.0083^{* *}$ & $(0.0287)$ & $0.084^{* * *}$ & 0.6706 & $0.1135 * * *$ & $(2.5163)^{* *}$ & $0.1107 * *$ & $(3.2935)^{* * *}$ \\
\hline Short-term debt & $(0.2453)^{* *}$ & $(0.0001)$ & $0.7294 * * *$ & $(0.0509)^{* * *}$ & $0.2417 * * *$ & $0.556^{* * * *}$ & $(0.020)$ & $1.0396^{* * *}$ & 0.0006 & $1.067 * * *$ & $0.0029 * * *$ \\
\hline Debt-to-capital ratio & $(0.0016)$ & $7.2547 * *$ & $(0.821)$ & $(-0.0677)$ & 0.1252 & 0.014 & $(2.1772)^{* * *}$ & 0.0303 & $(0.0002)$ & 0.0679 & $0.0006^{* * *}$ \\
\hline $\begin{array}{c}\text { Dynamics of net sales } \\
\text { revenues }\end{array}$ & $(9.2429)$ & $(0.2159)^{*}$ & $(0.168)$ & $(0.0912)^{* * *}$ & $(0.1890)$ & $(1.988)^{* * *}$ & $(0.0001)$ & $(2.0631)^{* * *}$ & 0.0007 & $(2.002)^{* * *}$ & $(0.704)^{* * *}$ \\
\hline Adjusted R-squared & 0.89 & 0.78 & 0.77 & 0.87 & 0.80 & 0.84 & 0.88 & 0.79 & 0.87 & 0.81 & 0.78 \\
\hline
\end{tabular}

*** significant at $1 \%$ level, ${ }^{* *}$ significant at $5 \%$ level, * significant at $10 \%$ level, (...) negative values.

Table 15. Linking the performance of companies in the WIG-mining index to the presentation of non-financial CSR information in the 2013-2018 period.

\begin{tabular}{|c|c|c|c|c|c|c|c|c|c|c|c|}
\hline \multirow{2}{*}{ Variable } & Model 1 & Model 2 & Model 3 & Model 4 & Model 5 & Model 6 & Model 7 & Model 8 & Model 9 & Model 10 & Model 11 \\
\hline & \multicolumn{3}{|c|}{ Area 1} & Area 2 & \multicolumn{7}{|c|}{ Area 3} \\
\hline
\end{tabular}




\begin{tabular}{|c|c|c|c|c|c|c|c|c|c|c|c|}
\hline Const & $4.8405^{* * *}$ & 1.5586 & 1.5586 & $8.3277 * * *$ & $(1.238) * * *$ & $10.7286 * * *$ & $(5.2131)^{* * * *}$ & $4.8117 * * *$ & $(0.2904)$ & $4.8117^{* * *}$ & $8.2769 * * * *$ \\
\hline ROA & $(0.0704)^{* * * *}$ & $(0.2268)$ & $(0.2268)$ & $(0.123)^{* * * *}$ & $(4.1377) * *$ & $(0.1499)^{* * * *}$ & (0.3017) & $(0.0733)^{* * *}$ & $(0.2264)$ & $0.0845^{* * * *}$ & $(0.1085)^{* * * *}$ \\
\hline Book value & $0.098^{* * *}$ & $(0.6032)$ & $(0.6032)$ & 0.0533 & $(0.3222)$ & 0.0292 & $(3.0157)^{* * * *}$ & $0.0845^{* * *}$ & $(1.4782)^{* *}$ & $0.5562 * * *$ & 0.0434 \\
\hline Short-term debt & $0.8718^{* * * *}$ & $(0.0019) * * *$ & $(0.0019) * * *$ & 0.6378 & $(2.3642)^{* * * *}$ & $0.6248 * * *$ & $0.0025^{* * * *}$ & $0.5562 * * *$ & $(0.0017)^{* * * *}$ & 0.0146 & 0.5697 **** \\
\hline Debt-to-capital ratio & $(0.1192)$ & $(0.0015) * *$ & $(0.0015)^{* *}$ & 0.0522 & 0.0008 & 0.0828 & 0.0006 & 0.0146 & $(0.0014)^{* *}$ & $(1.5504)^{* * * *}$ & 0.0542 \\
\hline $\begin{array}{c}\text { Dynamics of net sales } \\
\text { revenues }\end{array}$ & $(1.6572) * * *$ & $0.6715^{* * *}$ & $0.6378^{* * * *}$ & $(1.238) * * *$ & 0.0006 & $(1.3278)^{* * * *}$ & 0.0007 & $(1.5504)^{* * *}$ & $(0.0733)^{* * * *}$ & $(0.2904)$ & $(1.406)^{* * * *}$ \\
\hline
\end{tabular}

*** significant at $1 \%$ level, $* *$ significant at $5 \%$ level, * significant at $10 \%$ level, (...) negative values. 
One may conclude that the company's ability to earn profits and the efficiency of managing its assets, as well as its value and the income dynamics building the previous two variables, are positively related to the explained variable: the number of sentences. This may mean that companies are eager to describe in words the companies' aptitude to generate economic benefits for companies. The final, third model in the first area explained the associations of the "number of difficult words" variable with the performance of the units studied. The number of difficult words was construed as the number of words with more than four syllables. Such words can generally be deemed long and not commonly present in the average person's vocabulary. The model included 2 variables that significantly affected the number of difficult words. These variables were ROA - negatively related, as well as short-term debt - positively related. The use of difficult words in the case of ROA means that difficult words were used to describe the company's ability to earn profits or its management efficiency in cases where the ROA was low, whereas if it was high, the number of difficult words was rather low. In contrast, the relationship with the number of difficult words was positive when describing short-term debt. This may indicate that companies with significant short-term liabilities are more likely to use words that are difficult for the average person and generally absent from the basic vocabulary of a typical Pole to describe these circumstances as well as their possible negative impact on the companies' functioning. As such, one may conclude that the higher the level of short-term debt, the higher the number of difficult words used. On the other hand, a single econometric model was formulated in area two of statistical text analysis concerning the study of the average length of text units. The explained variable was the variable indicating the average word length. In this case, a negative relationship was found between the explained variable and book value and net sales revenue dynamics. The implication is that the book value of the company affected the average word length - i.e. the net worth of a business entity is negatively related to the average word length, which is the result of dividing the number of all syllables that a text consists of by the number of all words in the text. A negative relationship is observed between average word length and book value, which means that the longer the words the lower the book value. In the third area of text analysis - text as a percentage - seven models were created and numbered from five to eleven. For model number five, which explained the variable percentage of difficult adjectives in the examined CSR report texts, it was determined that the short-term debt, debt-to-capital ratio, and net sales revenue dynamics variables showed a negative relationship with the explained variable. The results indicate that companies with short-term debt, construed as the company's ability to settle its own obligations within twelve months, show a negative relationship in this regard. This may mean that the more difficult a company's ability to settle its short-term obligations is, the lower the percentage of difficult adjectives used to describe it. A similar tendency occurs when a company is required to describe the amount of debt relative to equity. The higher the debt financing the equity, the lower the percentage of difficult adjectives that describe these circumstances. The last variable showing a negative relationship was labelled the ratio of the dynamics of net sales revenue to the percentage of difficult adjectives in the text. This means that an increase or decrease in net sales compared to the previous year has a negative effect on the percentage use of difficult adjectives. It can be concluded that the greater the decrease in dynamics, the fewer difficult adjectives are used. In the case of the sixth model - which explains the relationship between the percentage of difficult verbs variable and the other variables - a negative relationship was shown for the book value and net sales dynamics variables. These variables show a strong negative relationship, which may mean that fewer difficult verbs are used to describe the net worth of a business entity when the ratio decreases. On the other hand, when there is a change in the value of net sales ratio compared to previous years, there is also a change in the percentage of difficult verbs in the text - as in the case of book value. In model seven, where the explained variable is the percentage of difficult nouns, four explanatory variables were identified; these variables show a relationship between the explained variable. These variables are ROA, book value, sales revenue dynamics - negative relationship, as well as short-term 
debt - positive relationship. That is, the ROA variable indicating the company's ability to earn profits and its management efficiency is negatively related to the percentage of difficult nouns in the text. This suggests that the lower the company's ability to earn profits, the lower the percentage of difficult nouns. A similar situation applies to the net worth of the business entity as well as the net sales revenue dynamics. Both of these variables were described using a lower percentage of difficult adjectives. On the other hand, a positive relationship was observed for the variable that determines the company's ability to settle its short-term liabilities. The greater the ability to settle liabilities, the greater the percentage of difficult nouns in the text. Model eight identifies a positive relationship between the following variables: percentage of difficult words and ROA, book value, short-term debt, and a negative relationship between sales revenue dynamics. This means that the percentage of difficult words is positively related to the company's ability to generate profits and its net worth, including the ability to pay short-term liabilities. In contrast, a negative relationship was found in cases where there was a change in the net sales dynamics compared to the previous year. In such a case, the percentage of difficult words may decrease. The ninth model points to the positive relationships between the percentage of adjectives and book value and short-term debt. Additionally, a negative relationship is evident between the percentage of adjectives in the text and ROA and sales revenue dynamics. This means that the percentage of adjectives in the examined reports of WIGenergy companies was positively influenced by the given company's net worth and its ability to settle short-term liabilities. In contrast, a negative relationship was discovered in the case of the company's ability to generate profits and the change in net sales dynamics. Companies did not describe such circumstances using a significant number of adjectives. The second-to-last model describing the WIG-energy index companies indicated that the percentage of nouns in the text is negatively affected by ROA and sales dynamics. In contrast, short-term debt has a positive impact. This means that the percentage of nouns depends on the company's ability to generate profits - the better its financial condition, the higher the percentage of nouns used. Additionally, the percentage of nouns is affected by the company's ability to settle its short-term liabilities. The percentage of nouns is negatively affected by the change in net sales dynamics compared to the previous year. In model eleven, the variable "percentage of verbs in the text studied" shows a positive relationship with ROA and short-term debt and a negative relationship with net sales revenue dynamics. This means that the percentage of verbs used in CSR reports may increase when the company shows a greater ability to earn profits and the efficiency of its resource management increases. This also applies to the company's ability to pay its short-term liabilities within twelve months. A negative association between the variables is evident in the relationship of the percentage of verbs used to net sales dynamics changes. This may mean that companies use a smaller percentage of verbs when the explanatory variable negatively affects the explained variable.

Table 13 shows the results of econometric modelling using panel regression for companies listed in the WIG-fuel index. Three models were created in the first area of text analysis. The first model examined the relationship between the number of sentences and the variables selected for the model itself. Based on this, a positive relationship was found for book value and a negative relationship for ROA and short-term debt. Book value, defined as the net worth of an economic entity, had a positive impact on the number of sentences in CSR reports, whereas a negative impact was identified in the case of deteriorating financial condition of a company or difficulties with short-term debt settlement. When examining the relationship between word count and the variables, model two identified a positive relationship between book value and debt-to-capital ratio and a negative relationship between ROA and sales revenue dynamics. WIG-fuel index companies used a large number of words to describe the business entity net worth, as well as how equity was financed through debt incurred. The number of sentences was positively related to the performance in these areas. In contrast, there was a negative relationship in the areas of profitability and asset management efficiency and changes in net sales growth. For the 
final model in area one of the text analysis, the explained variable - i.e. the number of difficult words - shows a positive relationship with short-term debt and a negative relationship with ROA. This may mean that business entities are willing to use difficult words at times when their performance is unsatisfactory. Conversely, if the opposite is true, such words are not used.

A single model was created in the second area of text analysis concerning the average text unit length; its explained variable was the average word length expressed in syllables. The explained variable was negatively related to the following three variables: ROA, short-term debt and net sales revenue dynamics. As such, the length of words used in CSR reports - expressed in syllables - was negatively related to the company's ability to generate profits and negatively related to the ability to settle short-term liabilities; additionally, it was negatively related to the net sales revenue dynamics. This may mean that the companies researched used words with a large number of syllables when the performance of the explanatory variables deteriorated, that is, when the companies' financial condition deteriorated.

Models 5 to 11 present the third area of text analysis. Model five explains the relationship between the percentage of difficult adjectives and the selected explanatory variables. A positive relationship was identified between the percentage of difficult adjectives and short-term debt and a negative relationship between the explained variable and ROA. Companies listed in the WIG-fuel index used an increasing number of difficult adjectives as the short-term debt ratio was rising. As such, one may conclude that an increase in the debt ratio caused an increase in the percentage of difficult adjectives used. This is different when it comes to evaluating asset management efficiency. In this case, there is a negative relationship and a decrease in management efficiency may cause an increase in the percentage of difficult adjectives while an increase in management efficiency may cause a decrease in the percentage of difficult adjectives used in CSR reports. Model six explained the relationship between the percentage of difficult verbs in CSR reports including information on the performance of business entities. In this case, a positive relationship was found for the book value and short-term debt variables. In contrast, negative correlations were identified for ROA and net sales revenue dynamics. It is noticeable that the percentage of difficult verbs used depended on the company net worth. This means that the net worth and the percentage of difficult verbs increase in an even manner. Additionally, the increase in short-term debt caused an increase in the percentage of difficult verbs used. In contrast, the company's ability to earn profits was negatively related to the percentage share of difficult verbs. This may indicate that an increase in ROA can result in a decrease in the percentage of difficult verbs and vice-versa. In the next model discussed, model seven, the explanatory variable was negatively related to the debt-to-capital ratio. This may mean that the percentage of difficult nouns was increasing and the debt-to-capital ratio was decreasing. The description of debt's proportion in equity financing depended on share performance. The higher the proportion of debt to equity, the lower the percentage of difficult nouns used. Similarly, the lower the proportion of debt to equity the higher the percentage of difficult nouns. Model eight explained the relationship between the variable of the percentage of difficult words in relation to the business entity's performance. In this case, a positive relationship was found for the book value and short-term debt variables. On the other hand, negative relationships were determined for the ROA and net sales revenue dynamics variables. This means that as the percentage of difficult words increases, the net worth of the business entity increases as well, as does the short-term debt, i.e. the value of liabilities that must be settled within twelve months. The increase in the percentage of difficult words relative to the company's ability to generate profits is negative. This may mean that the share of difficult words increases when the ability to generate profits decreases. The same relationship exists between the percentage of difficult words and the net sales revenue dynamics. As such, the lower the revenue dynamics, the higher the percentage of difficult words used in the CSR reports of the WIG-fuel index 
companies examined. Model 9 explains the relationship between the variable "percentage of adjectives" in the CSR reports in relation to the explanatory variables. Two variables were determined to have a negative relationship, i.e. ROA and book value. This means that if the ratio of profit to the value of the companies' assets increases, the percentage of adjectives may decrease. Similarly, a change in book value negatively affects the percentage of adjectives in the text.

In model ten, the explained variable was the percentage of nouns in CSR reports. It was explained by the following explanatory variables: a positive relationship was found for the variable book value and short-term debt, whereas a negative relationship was found for ROA and net sales revenue dynamics. The model explained the positive relationship between the percentage of nouns in relation to the net book value of the companies. This means that the higher the net book value of the surveyed companies, the higher the percentage of nouns, and the higher the short-term debt, the higher the percentage of nouns. The situation is opposite for the variable representing the financial situation of the company and the net revenue growth. This means that the higher the percentage of nouns in CSR texts, the worse the financial situation of companies and the lower the level of net sales revenue growth. On the other hand, the better the financial standing of companies and the higher the level of net sales revenue growth, the lower the percentage share of nouns. The last, eleventh model explaining the percentage of verbs in CSR reports identified variables that form a relationship with it. A positive relationship is obtained for shortterm debt and debt-to-capital ratio, while a negative relationship is obtained for book value and net sales revenue growth.

In the last studied index of companies listed on the Warsaw Stock Exchange, WIGmining, the association between companies' performance and non-financial information on CSR is summarised in Table 14. Three models were created in the first area of text analysis. The first model examined the relationship between the number of sentences and the explanatory variables. Significant relationships with the number of sentences were shown for the following variables: negative relationship: ROA and net sales revenue growth; positive relationship: book value and short-term debt. In the case of a positive relationship, the results indicated that the net worth of the business entity increased along with the number of sentences. A similar situation was noted in the case of sales revenue growth - as the sales revenue growth increased, the number of sentences in the examined CSR reports increased. Meanwhile, a negative relationship was noted for the company's ability to generate profit and asset management efficiency. A relationship becomes apparent. For example, when ROA decreases, the number of sentences increases. For the second model that explains the relationship between the number of words and the independent variables, the following results were obtained. A positive relationship was identified between word count and net sales revenue growth. Meanwhile, a negative relationship was found for short-term debt and debt-to-capital ratio. Subsequently, for the third model that explained the relationship between the number of difficult words and the independent variables, it was found that a positive relationship was shown by the net sales growth and a negative relationship was identified with regard to the number of difficult words recorded for short-term debt and debt-to-capital ratio. This means that the number of difficult words increased as the growth rate of net sales revenue increased and may have decreased if there were changes in short-term debt, i.e. if the liabilities could not be paid within twelve months. In addition, a negative relationship was noted for equity financing with debt. The higher the degree of debt financing, the lower the number of difficult words in the text.

The second area analysed was the area discussing average text unit lengths. In this area, one model was formulated to explain the relationship between average word length (measured in syllables) and its explanatory variables. Regression results indicated that two variables were dependent. The relationship was negative. The first variable 
negatively related to average word length was the ROA variable and the second one was net sales revenue growth. This could mean that the average word length expressed in syllables may have decreased as the company's ability to generate profits and improve its financial situation increased. In addition, it can be concluded that as the net sales revenue growth rate increases, the average number of syllables in words decreases.

The last area analysed was the text area in percentage. Seven models were formulated in this area. The fifth model explaining the percentage of difficult adjectives identified that two variables, ROA and short-term debt, have a negative relationship with this variable. This means that a company's ability to generate profits does not depend on the percentage of difficult adjectives in the text and on its ability to pay its current liabilities within twelve months. Meanwhile, a positive relationship was identified with regard to short-term debt in model six. In contrast, a negative relationship existed in relation to ROA and net sales revenue growth. The ability to generate profit was negatively related to the percentage of difficult verbs. This may mean that as the ability to generate profits increases, the percentage of difficult adjectives decreases, and as the growth rate of net sales revenue decreases, the percentage of difficult adjectives increases. The seventh model explained the percentage of difficult nouns. The variables that explained this variable were book value and short-term debt. Book value showed a negative relationship while short-term debt showed a positive relationship. This meant that as the ability to pay short-term debt increased, the percentage of difficult nouns increased and as the net worth of the company increased, the percentage of difficult nouns may have decreased. The eighth model explained the relationship of the variable of percentage of difficult words in the text of CSR reports and determined the variables that influenced it. These variables were ROA, book value, short-term debt and net sales revenues growth. A negative relationship was identified for the following variables: ROA and net sales revenue growth. A positive relationship was identified for book value and short-term debt. This means that as the book value of the company increases and as the ability to pay liabilities within twelve months increases, the percentage of difficult words in the text of CSR reports increases. It is different for the ability to generate profits and for the net sales revenue growth. The study shows that the relationship with the percentage of difficult words is negative, which may imply a decrease in the percentage of difficult words in describing ROA and net sales revenue growth. In the ninth model explaining the relationship between the percentage of adjectives and the variables explaining them, it was determined that as many as four variables are negatively related to it. These variables are book value, short-term debt, debt-to-capital ratio, net sales revenue growth. This means that the percentage of adjectives may be higher when the values of the individual variables decrease. The penultimate model explaining the variable of percentage of noun content in the text of CSR reports showed that this variable is explained by the following explanatory variables: a negative relationship was identified for the variable of debt-to-capital ratio and a positive relationship was found for ROA and book value. This means that as the company's ability to generate profits increases, the percentage of nouns in the text increases. The last, eleventh model explained the variable of percentage of verbs in the text of CSR reports and indicated that the variable has a negative relationship with the following variables: ROA and net sales revenue growth.

\section{Conclusions}

The study was conducted to answer the research questions on Are there differences in the linguistic structure in the studied CSR reports of selected indices of companies listed on the Warsaw Stock Exchange? and Are there relationships between financial and non-financial information in the reports of the listed companies under study?

This problem is still unsolved and many researchers are trying to determine what tools available in science and practice could help answer these nagging questions. The answers to these questions are important contributions to the development of reporting, 
including corporate reporting. This is related to improving the presentation of reporting information not only on the financial results of the company's activities but also on the environmental impact and combating of the negative effects of these activities. Examples of such research include studies on improving financial reporting disclosures in farms $[61,62]$ or pharmaceutical companies [63]. A disadvantage of this research is the lack of combination of qualitative and quantitative variables, which, in the opinion of the authors, is the basis for evaluation.

Therefore, for research objectives formulated in this way, two research hypotheses were defined: There are significant differences in the linguistic structure in the studied CSR reports in Poland (H1), and There is a relationship between business performance and description of business activities in reporting corporate social responsibility (CSR) information (H2).

The research made it possible to analyse and subsequently evaluate the linguistic structure in the studied Corporate Social Responsibility reports, measured in the following three areas of statistical text analysis: text in numbers, average length of text units, text in percentages, and determination of whether there is a relationship between financial performance and description of CSR activities, measured using econometric modeling. All of the tools and methods used were original contributions to science.

Hypothesis one was not confirmed in its entirety, as it was found that reports within each WIG index had similar values across the three areas examined, i.e. the percentage of nouns in each of the years examined in each of the WIG indexes examined was the most salient part of speech. Subsequently, this relationship was confirmed in the other parts of speech. Little difference was seen in the average number of sentences, excluding the number of words, as the highest average number of words was used in WIG-mining and the lowest in WIG-energy.

Furthermore, it was found that the ROA variable had a positive relationship with the number of sentences only in one case while in the case of other variables, it was a negative relationship in each of the stock indexes. This may mean that the more unfavourable a company's net income to asset ratio is, the less willing companies are to describe it. In addition, it was found that in most cases, there is a positive association between the book value of a business entity and the explanatory variables. This was evident in the WIGenergy sector, where only a negative relationship existed in the area of percentage association with verbs and difficult nouns.

Research showed that there is a relationship between qualitative and quantitative variables. This relationship can be positive or negative. The research confirms that companies are more willing to describe favourable areas of the company's operations, while they are less enthusiastic about describing difficulties they encounter while conducting business activities or worse financial results. The results of the analysis conducted strengthen the theoretical arguments in favour of using obfuscation as a tool to hide poor performance of selected WIG-energy, WIG-fuel, WIG-mining companies. These results contribute to both value relevance and opportunistic perspectives [64] with respect to predicting the relationship between firm performance and corporate disclosure [42].

This paper makes an important contribution to the research on CSR disclosure and its relationship with the financial performance of companies listed on the Warsaw Stock Exchange (Poland). To the author's knowledge, similar studies have not been conducted by researchers. This study also has several practical implications. The approach used in this study may allow stakeholders to conduct preliminary assessments of a company's actual CSR performance without further investigation of actual, hard-to-find CSR performance data. The survey results can also help policymakers support ongoing initiatives promoting the use of plain language in public disclosure documents.

Author contributions: Conceptualisation, M.W.; methodology, M.W.; software, M.W.; validation, M.W.; formal analysis, M.W.; investigation, M.W.; resources, M.W.; data curation, M.W.; writing original draft preparation, M.W.; writing - review and editing, M.W.; visualisation, M.W.; supervision, M.W.; project administration, M.W.; funding acquisition, M.W. 
All authors have read and agreed to the published version of the manuscript.

Funding: This research was funded by Faculty of Economics, Poznań University of Life Sciences.

Conflicts of interest: The author declares no conflict of interest.

\section{References}

1. Van Laer, T.; Ruyter, K. D.; Vsconti, L.M. The extended transportation-imagery model: A meta-analysis of the antecedents and consequences of consumers' narrative transportation. Journal of Consumer Research 2014, Volume 40 (5), pp. $797-817$.

2. Herskovitz, S.; Crystal, M; The essential brand persona: Storytelling and branding. Journal of Business Strategy 2010, Volume 31 (3), pp. 21-28.

3. Kaufman, B. Stories that sell, stories that tell. Journal of Business Strategy 2003, Volume 24 (2), pp. 11-15.

4. Delgado-Ballester, E.; Fern ández-Sabiote, E. Once upon a brand": Storytelling practices by Spanish brands. Spanish Journal of Marketing - ESIC 2016, Volume 20, Issue 2, pp. 115-131. DOI: https://doi.org/10.1016/j.sjme.2016.06.001.

5. Fog, K.; Christian B.; Yakaboylu B. Storytelling. Branding in practice, 2nd ed.; Springer-Verlag Berlin Heidelberg, $2005 ;$ pp.254. DOI 10.1007/978-3-540-88349-4.

6. Bloomfield, R. J. Accounting as the Language of Business. Accounting Horizons 2008, Volume 22 No. 4, pp. 433-436. DOI: 10.2308/acch.2008.22.4.433.

7. Avery, H. G . Accounting as a language. The Accounting Review 1953, Volume 28(1), pp. 83-87.

8. Evans L. Observations on the changing language of accounting. Accounting History 2010; Volume 15(4), pp. 439-462. DOI:10.1177/1032373210373619.

9. Graham, C. Teaching accounting as a language. Critical Perspectives on Accounting 2013, Volume 24 (2), pp. 120-126. DOI: 10.1016/j.cpa.2012.01.006.

10. Beattie, V.; McInnes, B.; Fearnley, S. A Methodology for Analysing and Evaluating Narratives in Annual Reports: A Comprehensive Descriptive Profile and Metrics for Disclosure Quality Attributes. Accounting Forum 2004, Volume 28 (3), pp. $205-236$. DOI:10.1016/j.accfor.2004.07.001.

11. Beattie, V. Accounting Narratives and the Narrative Turn in Accounting Research: Issues, Theory, Methodology and a Research Framework. The British Accounting Review 2014, Volume 46, pp. 111-134. http://dx.doi.org/10.1016/j.bar.2014.05.001.

12. Llewellyn, S. Narratives in accounting and management research. Accounting, Auditing \& Accountability Journal 1999, Volume 12 No. 2, pp. 220-237. https://doi.org/10.1108/09513579910270129.

13. Couper-Kuhlen, E. Assessing and accounting. Studies in Interactional Sociolinguistics 2007, Volume 24, 81-119.

14. Węgrzyńska M. Zielona rachunkowość (Green accounting), Wydawnictwo Wyższej Szkoły Bankowej w Poznaniu, Poznań, 2013; pp.157. ISBN: 978-83-7205-316-9.

15. Gray, R. H. Accounting and environmentalism: an exploration of the challenge of gently accounting for accountability, transparency and sustainability. Accounting Organizations and Society 1992, Volume 17(5), pp. 399-426.

16. Gray, R. H. Current developments and trends in social and environmental auditing, reporting and attestation: A review and comment. International Journal of Auditing 2000, Volume 4 Issue 3, pp. 247-268. https://doi.org/10.1111/1099-1123.00316.

17. Gray, R. H. The social accounting project and accounting organizations and society: Privileging engagement, imaginings, new accountings and pragmatism over critique. Accounting Organizations and Society 2002, Volume 27(7), pp. 687-708. https://doi.org/10.1016/S0361-3682(00)00003-9.

18. Gray R. Is accounting for sustainability actually accounting for sustainability. . .and how would we know? An exploration of narratives of organisations and the planet. Accounting, Organizations and Society 2010, Volume 35, pp. 47-62. doi:10.1016/j.aos.2009.04.006.

19. Bebbington, K. J.; Thomson, I. Business conceptions of sustainability and the implications for accountancy, Certified Accountants Educational Trust, London, England, 1996, pp. 64. ISBN 1898291691.

20. Bebbington, J. Sustainable development: A review of the international development, business and accounting literature. Accounting Forum 2001, Volume 25 (2), pp. 128-157.

21. Bebbington, J. Accounting for sustainable development performance. CIMA, London 2007.

22. Cooper, C. The non and nom of accounting for (m)other nature. Accounting. Auditing and Accountability Journal 1992, Volume 5(3), pp. 16-39.

23. Cooper, C.; Taylor, P.; Smith, N.; Catchpowle, L. A discussion of the political potential of social accounting. Critical Perspectives on Accounting 2005, Volume 16, pp. 951-974. https://doi.org/10.1016/j.cpa.2003.09.003.

24. Jones, M. J. Accounting for biodiversity: A pilot study. British Accounting Review 1996, Volume 28(4), pp. $281-303$.

25. Jones, M. J. Accounting for biodiversity: Operationalising environmental accounting. Accounting Auditing and Accountability Journal 2003, Volume 16(5), pp. 762-789. https://doi.org/10.1108/09513570310505961.

26. Killian, S. No accounting for these people: Shell in Ireland and accounting language. Critical Perspectives on Accounting 2010. Volume 21, Issue 8, pp 711-723. https://doi.org/10.1016/j.cpa.2010.08.001.

27. Beyer, A.; Cohen, D. A.; Lys, T. Z.; Walther. B.R. The financial reporting environment: Review of the recent literature. Journal of Accounting and Economics 2010, Volume 50, Issues 2-3, pp. 296-343. https://doi.org/10.1016/j.jacceco.2010.10.003.

28. Taliento, M.; Favino, Ch.; Netti, A. Impact of Environmental, Social, and Governance Information on Economic Performance: Evidence of a Corporate 'Sustainability Advantage from Europe, Sustainability 2019, Volume 11(6), pp. 1738; https://doi.org/10.3390/su11061738. 
29. Porter, M.E.; Kramer, M.R. The Big Idea: Creating Shared Value. How to reinvent capitalism - And unleash a wave of innovation and growth. Harvard Business Review 2011, Volume 89, pp. 2-17.

30. Damodaran A. Wycena firmy. Storytelling i liczby. Wydawnictwo Poltext, Warszawa, Polska, 2019; pp. 352. ISBN: 978-83-7561784-9.

31. American Accounting Association (AAA), Report of the Committee on Non-financial Measures of Effectiveness. The Accounting Review (Supplement to 46, 1971).

32. American Accounting Association, Report of the Committee on Measurements of Effectiveness for Social Programs, fie Accounting Review (Supplement to 47, 1972), pp. 337-396.

33. American Accounting Association, Report of the Committee on Environmental Effects of Organizational Behavior, 77 Accounting Review (Supplement to 48, 1973), pp. 73-119.

34. American Accounting Association, Report of the Committee on the Measurement of Social Costs, The Accounting Review (Supplement to 49, 1974), pp. 99-1 13.

35. American Accounting Association. Report of the Committee on Accounting for Social Performance, The Accounting Review (Supplement to 50, 1975), pp. 38-69.

36. American Accounting Association, Report of the Committee on the Social Consequences of Accounting Information (American Accounting Association, 1978).

37. American Institute of Certified Public Accountant, The Measurement of Corporate Social Performance (AICPA, 1976).

38. American Institute of Certified Public Accountants, Objectives of Financial Statements (AICPA, 1973).

39. The Conceptual Framework for Financial Reporting 2010. Available online: https://people.unica.it/gianluigiroberto/files/2015/09/Conceptual-Framework-IASB-2010-1.pdf (accessed 7.07.2021).

40. Healy, P.M.; Palepu K.G. Information asymmetry, corporate disclosure, and the capital markets: A review of the empirical disclosure literature. Journal of Accounting and Economics 2001, Volume 31 Issues 1-3, pp. 405-440. https://doi.org/10.1016/S0165-4101(01)00018-0.

41. Urquiza, F.B.; Navarro, M.C.A, Trombetta, M. Disclosure indices design: does it make a difference? Revista de ContabilidadSpanish Accounting Review 2009, Volume 12 - № 2 pp. 253-278 ISSN: 1138-4891.

42. Nazari, J.A.; Hrazdil, K.; Fereshteh, M. Assessing social and environmental performance through narrative complexity in CSR reports. Journal of Contemporary Accounting \& Economics 2017, Volume 13, Issue 2, pp. 166-178. https://doi.org/10.1016/j.jcae.2017.05.002.

43. Wiengarten, F.; Lo, Ch. K.; Lam, J. Y. How does Sustainability Leadership Affect Firm Performance? The Choices Associated with Appointing a Chief Officer of Corporate Social Responsibility. Journal of Business Ethics 2017, Volume 140(3), pp. 477-493. DOI: 10.1007/s10551-015-2666-5.

44. Verbeeten, F.H.M.; Gamerschlag, R.; Möller, K. Are CSR disclosures relevant for investors? Empirical evidence from Germany. Management Decision 2016, Volume 54 No. 6, pp. 1359-1382. https://doi.org/10.1108/MD-08-2015-0345.

45. Venkatraman, S. and Nayak, R.R. Corporate sustainability: an IS approach for integrating triple bottom line elements. Social Responsibility Journal 2015, Volume 11 No. 3, pp. 482-501. https://doi.org/10.1108/SRJ-11-2013-0136.

46. Wang, C.-J. Do ethical and sustainable practices matter? Effects of corporate citizenship on business performance in the hospitality industry. International Journal of Contemporary Hospitality Management 2014, Volume 26 No. 6, pp. 930-947. https://doi.org/10.1108/IJCHM-01-2013-0001.

47. Torugsa, N.A.; O’Donohue, W.; Hecker, R. Proactive CSR: An Empirical Analysis of the Role of its Economic, Social and Environmental Dimensions on the Association between Capabilities and Performance. Journal Business Ethics 2010, Volume 115, pp. 383-402. https://doi.org/10.1007/s10551-012-1405-4.

48. Quazi, A.; Richardson, A. Sources of variation in linking corporate social responsibility and financial performance. Social Responsibility Journal 2012, Volume 8 No. 2, pp. 242-256. https://doi.org/10.1108/17471111211234860.

49. Orlitzky, M.; Schmidt, F.L.; Rynes, S.L. Corporate social and financial performance:a meta-analysis. Organisation Studies 2003, Volume 24, pp. 403-41. https://doi.org/10.1177/0170840603024003910.

50. Hahn, T.; Figge, F. Beyond the Bounded Instrumentality in Current Corporate Sustainability Research: Toward an Inclusive Notion of Profitability. Journal Business Ethics 2011, Volume 104, pp. 325-345 (2011). https://doi.org/10.1007/s10551-011-09110 .

51. Nguyen, D.K.; Slater, S.F. Hitting the sustainability sweet spot: having it all. Journal of Business Strategy 2010, Volume 31 No. 3, pp. 5-11. https://doi.org/10.1108/02756661011036655.

52. Shen, CH.; Chang, Y. Ambition Versus Conscience. Does Corporate Social Responsibility Pay off? The Application of Matching Methods. Journal Business Ethics 2009, Volume 88, pp. 133-153. https://doi.org/10.1007/s10551-008-9826-9.

53. Clarkson P. M.; Li Y.; Richardson G.D.; Vasvari F.P. Revisiting the relation between environmental performance and environmental disclosure: An empirical analysis. Accounting, Organizations and Society 2008, Volume 33, pp. $303-327$. doi:10.1016/j.aos.2007.05.003.

54. Al-Tuwaijri S.A.; Christensen T.E.; Hughes K.E. The relations among environmental disclosure, environmental performance, and economic performance: a simultaneous equations approach. Accounting, Organizations and Society 2004, Volume 29, Issues 5-6, pp. 447-471. https://doi.org/10.1016/S0361-3682(03)00032-1.

55. Wiśniewski, T. Indeks RESPECT. Index jako inicjatywa Giełdy Papierów Wartościowych w procesie tworzenia zasad CSR na polskim rynku kapitałowym. Zeszyty Naukowe SGGW, Polityki Europejskie, Finanse i Marketing 2010, Volume (4(53)), pp. 301-311. 
56. GPW Benchmark. Available on line: https://gpwbenchmark.pl/ (accessed 10.01.2021).

57. Jacyno, M.; Korkosz-Gębska, J.; Maj, M.; Milewski, J.; Trębacz, D.; Wójcik, G. The socially responsible energy sector, Rynek Energii 2013, Volume Nr 6, pp. 3-12.

58. Portal of non-governmental organizations. Available online: https://fakty.ngo.pl/raporty (accessed 10.02.2021).

59. Standards GRI. Available online: https://www.globalreporting.org/standards/ (accessed 10.02.2021).

60. Jasnopis.pl. Available online: www.jasnopis.pl (accessed 5.05.2021).

61. Węgrzyńska M.; Pereira López X.; Veiga Carballido M. The scope of presentation of non-financial information in financial statements of farms - the example of crop production. Theoretical Journal of Accounting 2018, Volume (100 (156)), pp. 191-210. DOI: 10.5604/01.3001.0012.7318.

62. Węgrzyńska M. Improving the quality of reporting information in the annual financial statements of farms: A case study of Poland and Spain. European Research Studies Journal 2021, Volume XXIV, Issue 2, pp. 1180-1193, 2021. DOI: 10.35808/ersj/2181.

63. Dyczkowska J. Ujawnienia niefinansowe w obszarze działalności badawczo-rozwojowej. Praktyki europejskie spółek biofarmaceutycznych. Wydawnictwo Uniwersytetu Ekonomicznego we Wrocławiu, Polska, 2019; pp.466. ISBN: 978-83-7695751-7.

64. Merkl-Davies D.M.; Brennan N.M; Discretionary disclosure strategies in corporate narratives: incremental information or impression management? Journal of Accounting Literature 2007, Volume 27, pp. 116-196. 